\title{
Treinta años de poesía y bohemia (1890-1920)
}

Allen W. PhILlips

Universidad de California, Santa Bárbara

Al continuar mi trabajo sobre la bohemia española hacia finales de siglo XIX y principios del actual, publicado en la entrega anterior de Anales de Literatura Española, abordo el tema desde otro ángulo. En la primera parte quise señalar algunos aspectos de la bohemia española, basándome principalmente en los textos críticos a mi alcance y en las memorias de la época. Con otro enfoque más específico vuelvo ahora a los mismos años para estudiar ciertas obras representativas de un reducido número de poetas relacionados de una manera u otra con la bohemia de aquel tiempo. Así me limito por el momento a un solo género, reservando para otra ocasión el estudio del mismo tema en la narración y en el teatro.

Emprendida la presente tarea me di cuenta inmediatamente de ciertas dificultades que no pudieron ser del todo superadas. Sin duda, la cantidad de textos pertinentes es abrumadora, pero muchos de ellos son inhallables en las bibliotecas y hemerotecas públicas dentro y fuera de España. He logrado reunir, no obstante, materiales suficientes, si no pasan de ser parciales, para dar una idea acerca de las tendencias generales de la poesía bohemia del día.

En este período conflictivo, de gran complejidad ideológica y estética, pronto comienzan a oírse voces estridentes que se proponen liqui- 
dar las tradiciones literarias e institucionales. En toda esfera de la vida nacional se respiran aires de vitalización, y, al despertarse de largos años de estancamiento, España está en condiciones para comenzar la obra de renovación moderna. Tal programa revisionista no puede imponerse sin largas y denodadas luchas. Al exaltar los valores del Arte y de la Verdad, al mismo tiempo que despreciaban todo lo burgués, los bohemios rebeldes desempeñaron un papel no suficientemente reconocido. Los bohemios, de fuertes convicciones anarquistas o socialistas, y sus correligionarios los modernistas se sentían marginados por una sociedad insensible y, afirmando el culto de la propia personalidad libre y revolucionaria, combatieron el convencionalismo, así como la mediocridad y rutina. A la protesta social y política se añade naturalmente un criterio de independencia personal e intelectual, que se extendía a todas partes. Esas aspiraciones llevaron a la búsqueda de nuevas experiencias, dando a los bohemios fama de degenerados y decadentes, víctimas de toda clase de excesos amorales. Desde luego, la bohemia tiene remotas raíces en la vieja picaresca, pero se diferencia notablemente de aquella actitud desvergonzada ante el mundo al menos de una forma significativa: el idealismo. Se encuentra una excelente y exacta evocación de loa azares y fortunas del bohemio hacia finales del siglo en el libro de Ricardo Baroja Gente de la generación del 98 (Barcelona, Editorial Juventud, 1952, 17). Vale la pena recordar que aparentemente había titulado al principio su obra Bohemia del 98, pero luego optó por el título definitivo, porque algunos de los artistas que figuraban en sus memorias eran legítimos bohemios y otros muchos no lo fueron nunca:

Pero entre nosotros había algunos empedernidos bohemios. Vivían como podían, a salto de mata. Escribían en periódicos que no pagaban o que lo hacían muy mal; pintaban cuadros que no vendían; publicaban versos que nadie leía; dibujaban caricaturas que no quería nadie.

Los que llamo burgueses éramos señoritos de familia más o menos acomodada. Sabíamos que en nuestro domicilio el cocido estaba a punto a su hora; la cena, dispuesta entre ocho o nuevo de la noche, y la cama, abierta por la doméstica para cuando el señorito tuviera a bien acostarse.

Los bohemios dormían en casa de huéspedes, comían en restaurantes baratos o en alguna taberna. Su verdadera morada era el café.

El café era el gabinete de trabajo de los escritores, taller de los dibujantes. Desde las dos de la tarde hasta las horas de la madrugada iban de un café a otro. Asomaban de vez en cuando por la redacción de algún periódico para colocar artículos, versos.

Iban a las librerías de lance a liquidar restos de edición, ejemplares de libros regalados, a los que ni siquiera se arrancaba la dedicatoria escrita en la primera 
hoja. En cuanto reunían unas pesetillas se hundian en el café a charlar, a discutir, sin importarles un pito lo futuro. No había porvenir que se extendiera más allá de una semana.

Suelen distinguirse dos etapas históricas y dos tipos de vida bohemia. Primero, la romántica y sentimental, de sano optimismo y placeres inocentes, un pasado primaveral popularizado por Murger. Hay, sin embargo, otro rostro más realista, menos pintoresco e infinitamente más cerca de la vida real, un mundo miserable de pobreza y de hambre. Muchos bohemios modernos, muertas sus ilusiones juveniles, descienden a la categoria de hampones literarios que habitan un inframundo localizado en los cafés y tugurios de la ciudad. A veces es difícil separar de la golfemia y del hampa una legítima y auténtica bohemia, pero basta decir que el bohemio heroico mantiene su sueño azul sin venderse como los parásitos del café, cuya existencia depende casi exclusivamente del sablazo.

Hay por lo tanto dos extremos: una bohemia decorosa y admirable, la otra parasitaria, cuyos adeptos apenas salen del arroyo y las tabernas inmundas. Lo que sucede es que siempre habrá una bohemia artística, vivos los ideales románticos de independencia. Los elegidos superan la etapa desordenada de la vida, muchas veces pasajera y transitoria, mientra que los impotentes sin voluntad se hunden en las sombras nocturnas, destrozados precisamente por lo que más exaltan: los hábitos irregulares y anticonvencionales. Por su criterio de independencia y su actitud de protesta contra las injusticias sociales hay, pues, algo noble en el bohemio sincero y auténtico.

\section{Clasificación previa}

Me permito aventurar una clasificación sumamente precaria, como todo intento de esta índole, de los escritores bohemios de la época, la cual está pensada solamente para lograr un ordenado plan de trabajo, que no falsifique ni la cronología ni la historia literaria de aquellos tiempos. Por razones de comodidad se diferencian aquí dos promociones de bohemios en el período que me interesa (1890-1920), aunque a propósito quedan eliminados de la nómina otros artistas de alta categoría, que mantenían sin embargo estrechos contactos con los cenáculos del mundo bohemio (Darío, Gómez Carrillo, Valle-Inclán, et al.). En el primer núcleo de escritores figuran los siguientes nombres de muy distinta calidad, así como de bien definida personalidad: Manuel Paso, 
Joaquín Dicenta, Alejandro Sawa, Delorme, Nakens, Ernesto Bark, Pedro Barrantes, Antonio Palomero, Ricardo Fuente, Eduardo Zamacois, Enrique Paradas y seguramente algunos otros. En esta lista, sin duda incompleta, la mayoría pertenece a la llamada generación de gente nueva, anterior a la del 98, y también casi todos en alguna forma $\mathrm{u}$ otra eran germinalistas o al menos simpatizaban con las avanzadas causas sociales. Cabe advertir en seguida otra cosa: casi todos son prosistas. Solamente tres tienen sustanciosa obra en verso: Barrantes, $\mathrm{Pa}$ lomero y Paradas.

Todos estos escritores son tipos notables y vivían entregados a una existencia desordenada de café y a menudo se reunían en las salas de redacción de los periódicos liberales. Varios de esa promoción se hundieron en el alcohol y desaparecieron. Sin embargo, con la posible excepción de la persona de Pedro Barrantes, son mucho más que meros pícaros o hampones de la literatura. Alejandro Sawa, cuyo libro Iluminaciones en la sombra es el diario de un bohemio impenitente, y Joaquín Dicenta, dramaturgo y cronista, no están totalmente olvidados hoy y ocupan un modesto lugar en el balance artístico de ese momento de transición. Hacia los mismos años, muy poco después, algunos poetas que se iniciaron como modernistas constituyen una agrupación intermedia por su estrecha afinidad con los bohemios. Entre ellos los que más se destacaron con el transcurrir de los tiempos son Manuel Machado, Francisco Villaespesa y Felipe Sassone.

El tipo bohemio más profesional de la segunda promoción es, desde luego, Emilio Carrère, de abundante obra de poeta y prosista, a quien rodeaban muchos jóvenes aspirantes, acompañándole en los cafés de turno y de modo especial en el Café Varela, a donde iba con mayor. frecuencia. Ya nos acercamos a la época del pleno ultraísmo (1918-1920) y descuellan ahora tres tipos: Pedro Luis de Gálvez, Alfonso Vidal y Planas y Dorio de Gádex (Antonio Rey Moliné). Otros poetas (por ejemplo, Eliodoro Puche, Armando Buscarini, Xavier Bóveda) reconocerían a Cansinos-Assens como maestro y éste compartía hacia aquellos años el cetro artístico con Gómez de la Serna, firmemente establecida la famosa tertulia de Pombo desde 1915:

\section{Preámbulo: «Teófilo Pajares»}

Pronto hablaremos de los poetas bohemios, entre ellos Villaespesa y Carrère, pero antes de hacerlo y a modo de preámbulo quisiera refe- 
rirme brevemente a una conocida e importante novela de la vida bohemia del Madrid de 1910. Se trata de Troteras y danzaderas (1913) de Pérez de Ayala, obra que constituye, junto con Luces de bohemia (1920) de Valle, una cumbre de la novelística inspirada en el mundo literario español de aquellos días. La novela de Pérez de Ayala, llena de digresiones sobre temas de la literatura y el arte, así como la regeneración del país, es una obra cuya parte ensayística no estorba el placer con que se lee. Por lo demás, la novela tiene muchos puntos de semejanza con el primer esperpento de Valle: cada obra es de clave y ofrece así un auténtico testimonio vivo de la bohemia madrileña anterior a la primera Guerra Mundial. En ambos casos una realidad íntimamente conocida por los dos autores, inclusive el recuerdo de anécdotas del día, se transforma artísticamente; la visión de cada libro implica claros sobretonos tragicómicos; la misma ironía y el gesto teatralizado caracterizan a los personajes preocupados ante el fracaso nacional; y hasta se parecen las técnicas literarias de caricatura. Es excusado decir que tanto Teófilo Pajares («el príncipe de los poetas») como Max Estrella («poeta de odas y madrigales») viven envenenados de literatura, a menudo de segundo grado, puesto que esa exageración nace de una visión literaturizada y no de una auténtica experiencia vital ${ }^{1}$.

Para 1912, cuando escribió su novela satírica, Pérez de Ayala se había distanciado ya del Modernismo, y Troteras y danzaderas es una intencionada parodia del ambiente bohemio (modernista) en que se movían los personajes de la obra. Teófilo Pajares, que poblaba sus poemas de pálidas princesas y que «había decorado siempre sus versos con innúmeras alusiones al arte y a la mitología helénicos» ${ }^{2}$, es el prototipo del poeta modernista e indudablemente hay varios modelos reales para la creación del personaje novelesco. Como ha comprobado atinadamente Amorós, sin descontar del todo a Marquina, Teófilo tiene mucho más de Villaespesa y Carrère ${ }^{3}$. Por supuesto, muchas sátiras antimodernistas circulaban en aquel tiempo y a menudo Villaespesa era el blanco de esta pullas maliciosas por ser lo que Pérez de Ayala llama

1 Andrés Amorós. Vida y literatura en «Troteras y danzaderas», Madrid, Editorial Castalia, 1973. Éste es un indispensable libro crítico, en que se explican con acierto las claves de la novela.

2 Ramón Pérez de Ayala, Troteras y danzaderas, Madrid, Editorial Pueyo, 1930, 61.

3 Amorós, $O b$. cit., 185. 
«gárrulo urdidor de palabras inertes» (28). Pero es muy significativo que Verónica, al hablar con Alberto Díaz de Guzmán, portavoz de las ideas del autor acerca de la vida bohemia que sólo ha conocido en las óperas y las novelas recite los siguientes versos:

Soy poeta embrujado por rosas lujuriosas y por el maleficio de la luna espectral.

Mi carne ha macerado con manos fabulosas uno por uno cada pecado capital.

En el burgués estulto, mis guedejas undosas de bohemio suscitan una risa banal; mas él no advierte, bajo mi mugre, las gloriosas armas de caballero, ungido de ideal.

Son mi magnificencia y fasto principescos; adoro las manolas y los sueños goyescos; toda la España añeja triunfa a través de mí.

Con ajenjo de luna mi corazón se embriaga, y en mi yacija, porque la carne satisfaga, sus magnolias me ofrenda la princesa Mimí.

Recitado de memoria el poema, se afirma en el texto que pudo haber sido escrito por una docena de poetas, y la parodia del escritor bohemio se completa en el soneto que en realidad es de Pajares: se exalta una típica actitud ante la vida (caballero ungido del ideal) y la aparencia física (guedejas y mugre), así como algunos de los temas favoritos de la secta (ajenjo de luna, pecados capitales) ${ }^{4}$.

\section{Manuel Machado y dos poetas menores (Villaespesa, Sassone)}

Aunque los temas de la vida bohemia ocupan relativamente poco espacio en su obra total y se concentran de modo especial en un solo libro, la poesía de Manuel Machado, por su alta jerarquía de excelencia, merece abrir el rápido recorrido por algunos poetas que cultivaron esa modalidad artística. Es un escritor exquisito de múltiples registros a la vez que de profundas contradicciones, cultivadas a propósito para no descubrir a flor de piel su intimidad: aristocrático y callejero, vital y nihilista, canta sus penas y sus alegrías en versos cultos y populares. Muy influido por Verlaine, a quien tradujo finamente, es un poeta de

+ Para un comentario más detallado que el que aquí me propongo, véase Amorós, Ibidem, 184-187. 
matices No falta cierta ambigüedad en su actitud ante la vida, aunque la crítica, salvo notables excepciones (Dámaso Alonso, Gerardo Diego, Pedro Laín), haya concedido demasiada importancia a su pretendida superficialidad, que es a veces un simple pretexto para mitigar el hondo y sincero dolor de vivir. De ahí que su ligereza y su despreocupación sean máscaras de una indiferencia intencionadamente equívoca. No se puede negar, por supuesto, la evidente filiación modernista de Manuel Machado; es sin duda alguna una de las figuras más representativas y mejor dotadas del movimiento en la Península. Cabe agregar que el ser modernista, en los primeros años del siglo, no supone desinterés ante la problemática de España, nì desamor a la Patria.

En medio de la asfixia intelectual de la época, Machado luchaba por un ideal literario y rompió la rutina tanto ideológica como artística. En las páginas de La guerra literaria (Madrid, 1913) habla detenidamente de los cambios efectuados en el arte y cómo en aquel entonces fueron arrollados los dogmatismos estéticos en busca de una nueva libertad externa e interna en el arte. El Modernismo, pues, se impone sobre una retórica momificada y formalmente inmovilizada. Anarquía e individualismo, junto con un anhelo de actualidad, permiten al poeta dar al traste con los códigos y abrirse a la universalidad. Refiriéndose a su libro El mal poema (1909), años después, en su discurso académico (1938), que es otro autorretrato añadido a los ya publicados en verso, escribe Machado: «No sé qué infausta monomanía me acuciaba en aquella época - la época de mi MAL POEMA - a desnudar mi alma- que tampoco era mi alma verdadera, sino lo peor de ella - ante la pública consideración o desconsideración, que era más probable... ${ }^{5}$. Estos poemas de la ciudad escritos en un lenguaje intencionado prosaico y acanallado se concentran, aunque no exclusivamente, en El mal poema, y éste es el mismo Machado decadente que utiliza también el estilo coloquial en los logrados retratos y semblanzas en verso de sus amigos y compañeros de la vida bohemia (Dedicatorias, 1910-1922).

\footnotetext{
Manuel Machado, Unos versos, un alma y una época, Madrid, Ed. Diana, 1940, 32. En el mismo texto Machado se refiere nuevamente a su libro de 1909: «Siento hoy casi vergüenza de este libro en que se desnuda en público un alma lamentable y pecadora. Si bien es verdad que con una respulsión manifiesta a lä contumacia en el mal (80) [...] Todo esto es agrio, duro, detestable. Pero no era mi vida mucho más amable entonces. [...] Afortunadamente todo lo cambió pronto la mano de una mujer santa [...] que había sabido esperarme en nuestra Sevilla materna de vuelta de todas mis locuras $(85)$ ».
} 
Manuel Machado, acompañado por su hermano Antonio, frecuentaba en los primeros años del siglo los círculos bohemios tanto en $\mathrm{Pa}$ rís, donde conoció el simbolismo triunfante, como en Madrid, donde después hacía vida de café. Sobre su vida parisiense, en la primavera de 1899, escribe el poeta:

... Mi vida fue plenamente la que llevaban allí los estudiantes y los artistas jóvenes del mundo entero. Una bohemia sentimental y pintoresca, rica de ilusiones. Me embriagué - siguendo a Baudelaire- muchas veces y me enamoré muchas más. Una pésima vida de Arlequín para la que encontraba no sé cómo toda clase de facilidades. Con esta vida y en esta vida misma se mezclaban la frecuentación de los medios literarios; también bohemios, pero más dignificados por el arte y a los que a veces concurrían verdaderas sumidades de las Letras... ${ }^{6}$

La bohemia de Machado solía ser elegante y en cierto sentido estilizada, siempre chic y rebuscada, como diría un célebre autorretrato, sin rebajarse nunca a la sórdida que arrastró a tantos tipos para hundirlos por siempre en la noche inhóspita. Esa época de la más franca bohemia de Machado tiende a llegar a un razonable término hacia 1910 cuando el poeta establece su hogar y regulariza su vida?

6 Ibidem, 52-53.

Elegante en su economía verbal y enemigo de la ampulosidad, hace una poesia breve y verleniana que por sus temas anticipa a tendencias posteriores al parecer de Cansinos-Assens, que continúa «... Con sus evocaciones del París finamente bohemio, de los poetas y los pintores y las mimís rubias y las locas Colombinas y el champagne, influye en la formación de la escuela bohemia que acaudilla Carrère...» La nueva literatura, I, Madrid, Sanz Calleja, 1917, 188.

7 Manuel Machado se siente obligado en varias ocasiones a explicar El mal poema. Publica, hacia 1913, un curioso texto («Autocrítica. Carta al poeta Juan R. Jiménez»), en que expone al poeta de Moguer, de temperamento opuesto, algunas motivaciones de la poesía de El mal poema. Ricardo Gullón («Relaciones amistosas y literarias entre Juan Ramón Jiménez y Manuel Machado», Cuadernos Hispanoamericanos núm. 128-129, agosto-septiembre de 1960, 115-139) reproduce tan interesante página, también incluida en La guerra literaria (Madrid, Imprenta HispanoAlemana, 1913, 117-120) y de ella cito unos fragmentos pertinentes: «... Habrás recibido El mal poema, por el que te suplico que no me quieras mal. Conozco la delicadeza de tu espíritu, y sé que te chocan ciertas trivialidades y malsonancias de que por desgracia está lleno nuestro vivir. Pero creo haber haberte dicho en mi descargo que no sólo se canta lo que se ama, sino lo que se odia más cordialmente. En suma, todo lo que de veras nos impresiona [...] Cuán lejos de todo eso me veo yo mismo en El mal poema, y cuánta vergüenza me causa en el fondo haber dado a la luz y a la estampa algo que puede parecer cinismo de un libertino, no siendo en realidad más que impresiones de un enfermo muy sensible (137).» Véase también otra carta de Machado a Juan Ramón, probablemente de 1911, reproducida por Gullón, Ibidem, p. 130. 
Desde un primer momento escribía en París algunos de sus versos más personales e intimistas, que iban a integrar el libro hetereogéneos y muy verleniano de Alma (1902). En esta obra primeriza (sin tener en cuenta los libros escritos en colaboración con Paradas), producto en parte al menos de una bohemia sentimental como hemos indicado, el poema «Antífona» termina con estos versos tantas veces recordados:

¿Ven tú conmigo, reina de la hermosura;

hetarias y poetas somos hermanos!

Pasan algunos años y edita Machado su libro El mal poema. Ya se había apuntado una actitud nihilista, de franco cinismo y neurastenia en poesías anteriores, pero ahora ese mismo clima espiritual de lucha y desesperación se acentúa para culminar en el volumen de 1909, cuyos temas y tonos representan una notable novedad dentro del Modernismo. Desaparece ahora la vaguedad simbolista y la poesía de El mal poema (eco de Baudelaire) ya no sugiere e insinúa estados de ánimo, sino que en ella se anotan directamente, a veces en lenguaje coloquial, el lugar y el efecto de las experiencias vividas. Los temas y los escenarios no pueden ser más explícitos en poemas como «Yo, poeta decadente» e «Intenacional». Desde luego, está muy aparente en el libro la vertiente decadentista de Machado, y al respecto escribe con acierto Luis Antonio de Villena:

... El laude del epicureísmo elegante, del escepticismo abúlico - un tanto fatalista-, y el afán de atrapar la vida en el instante y en el placer, porque de lo demás, de lo que puede venir, nada se sabe... La indiferencia smart que roza, suavemente, el cinismo. El estar de vuelta, en la sensibilidad, de todas las cosas... ${ }^{8}$

Tampoco falta la exaltación a la mujer de vida fácil en poemas como «Mi Phriné» (poesía que recuerda muy de cerca a «Antífona») y a «Mimí, la modelo» (Caprichos).

En El mal poema un nuevo concepto de belleza se impone, y el poeta ve la realidad no por el prisma del arte y a través de reminiscencias de mundos exóticos, sino por los ojos de un bohemio cansado y desilusionado, víctima de sus ideales («Invierno»).

\& Luis Antonio de Villena, «Relectura de El mal poema de Manuel Machado. Notas sobre Modernismo y bohemia», Insula núm. 362, enero de 1977, 11.

Véase también mi artículo sobre Manuel Machado y el decadentismo: «Decadent elements in the Poetry of Manuel Machado», Waiting for Pegasus, Western Illinois University, 1979, 65-76. 
Para apreciar plenamente esta poesía nocturna y libertina, de la ciudad y sus habitantes, hay que leer solamente algunas estrofas como las siguientes:

De un cantar canalla tengo el alma llena, de un cantar de notas monótonas, tristes, de horror y vergüenza.

De un cantar que habla de vicio y de anemia, de sangre y engaño, de miedo y de infamia, iy siempre de penas!

De un cantar que dice mentiras perversas...

De pálidas caras, de labios pintados y enormes ojeras.

(«Nocturno madrileño»)

Y así llega el amanecer, totalmente desvalorizado, con todas las desilusiones inevitables procedentes de los excesos de la noche anterior:

El alba son las manos sucias

y los ojos ribeteados.

$Y$ el acabarse las argucias

para continuar encantos.

Livideces y palideces, y monstruos de realidad

Y la terrible verdad mucho más clara que otras veces.

(«La canción del alba»)

La actitud escéptica y hedonista, ya presente en Alma, se hace ahora mucho más aguda en algunas poesías del libro; el abatimiento espiritual se testimonia, más hondo sin duda, en otras («Última», por ejemplo); y la predisposición de aprovecharse del instante y acoger el placer más inmediato, modo de ser característico del bohemio que no sabe lo que le espera al día siguiente, está presente en varios poemas de la colección. Dada la naturaleza de esta desgarrada poesía no pueden faltar los feísmos de la vida moderna de la ciudad y, como se dijo, un lenguaje a menudo vulgar tiende a reforzar el llamado realismo del libro. Por supuesto al fondo de El mal poema cojea la sombra de Verlaine, aludido de modo directo en varias instancias, y como bien se sabe el poeta francés conocía íntimamente la vida desastrosa de la calle y del burdel, alcoholizado y engañado por la falsa mentira del vino. 
Villaespesa, poeta excesivamente dañado sin duda por su prodigioso don de improvisador, escribe entre 1899 y 1900 una serie de poemas agrupados luego en un delgado volumen publicado en 1902 con el título de El alto de los bohemios ${ }^{9}$, cuya poesía suave y refinada bien poco tiene que ver con la bohemia literaria y realista del Madrid de la época, ambiente del cual era buen conocedor el poeta. Dedicado a Antonio Machado, el poema que da el título de la obra describe la música doliente de una caravana errante de gitanos:
iAdustos bohemios, reyes andrajosos, que cruzáis del mundo los vastos confines, siempre pensativos, tristes y ojerosos, sollozando amores en vuestros violines...!
¿Parad un instante bajo mi ventana, y con vuestros cantos calmad mi amargura, que quiero mostrarte mi mano, gitana, para que me digas la buenaventura!

En la música que se aleja paulatinamente se llevan los sueños del poeta enamorado, quien se pregunta bajo qué balcones gemirá mañana la pálida bohemia. En el conjunto del libro se trata de una poesía muy de la época, de tono menor y sin estridencias, llena de jardines o parques viejos u otoñales, $\mathrm{y}$ de realidades embellecidas e impresionistas. Las bellas pero poco sustanciosas canciones de Villaespesa traen eco de la manera del primer Juan Ramón, aunque el alma más pagana del poeta de Almería se revela en los sonetos anacreónticos de la sección «Renacimiento». Sin embargo, al volumen anterior Luchas (1899), más característico quizá de los años funambulescos de Villaespesa (eran los tiempos de los cafés literarios, revistas y periódicos, su amistad con Dicenta y luego Carrère, todo como torbellino en el recuerdo de Juan Ramón) pertenece una poesía titulada «Bohemia». Aquí se trata, sí, de unos verdaderos bohemios, reunidos en torno de una mesa de taberna, que discutían con pasión sus proyectos y ensueños lúgubres para luego quedar dormidos a causa del opio de ajenjo (sobre ellos «la neurosis fatídica extendía / sus membranosas alas de murciélago»). En el diálogo intervienen primero Salvador Rueda, quien quiere morir ebrio de amor y de champaña, y luego Cansinos-Assens, calificado de poeta del trabajo y del pueblo, exclama:

9 Tengo a la vista sus Obras completas, IV, Madrid, Imprenta de M. García y G. Saez, 1916, volumen que incluye también Rapsodias. 
... Desearía

sucumbir en la brecha, defendiendo

al débil contra el fuerte, y contra el déspota

al oprimido pueblo.

¡Morir como un monarca, de mi sangre

en la púrpura envuelto!

Cuando le preguntan al poeta protagonista sobre el modo en que quisiera morir, se calla contemplando las vírgenes desnudas del techo. Los tres se duermen, y en sueños, los amigos habían muerto. Sólo acompaña el séquito funerario ( «formado de amarguras y pesares / de burlas y desprecios!») un perro vagabundo que aullaba. Por fin se despierta el poeta y un rayo de sol corona la cabeza del perro, que velaba el sueño de los tres bohemios.

El fecundo escritor y dramaturgo peruano Felipe Sassone, que tan bien conocía el mundillo literario del Madrid de nuestro siglo, y autor de una detalladas memorias (La rueda de mi fortuna, 1958) publicó en 1917 La canción del bohemio y otros poemas (Madrid, Sanz Calleja). Esta colección, con sentida dedicatoria a Rubén Darío y la reproducción del texto en prosa de su conmovedora despedida al maestro americano, se caracteriza por su poesía netamente modernista escrita bajo la clara influencia del nicaragüense. Buenos versos, al estilo de Prosas profanas, que reflejan el mismo sensualismo, a veces de fuentes grecolatina o versallesca, así como la ligera y galante modalidad parisiense cultivada por Manuel Machado (de quien se incluye un retrato en verso). En un poema autobiográfico se leen estos versos:

Peregriné vagando, fui bohemio arrivista; mezclé entre mis blasfemias alguna maldición; me enborrachó el ajenjo de un verso modernista y olvidé la ternura y olvidé la oración.

Gasté capa, chambergo y melenas de artista; apercibí a mis nervios, dormí a mi corazón, y fui un autoanalítico que se volvió egoísta enfriando en el cerebro su calor de emoción.

(«Breve historia de amor», II)

Se entrega a nuevas sensaciones y al vicio, oliendo el perfume de las flores maléficas de Baudelaire. No faltan en el libro, junto con los recuerdos madrigalescos, los motivos populares y las chulerias de los barrios madrileños. De la composición que da título al volumen se reproducen ahora algunas estrofas que dan la medida de la bohemia de Sassone, libre e idealista: 
Del ensueño soy cruzado, soy un pálido bohemio, siento el arte por el arte, sin buscar jamás el premio, $\mathrm{y}$ odio, loco de idealismo, la razón útil y seria.

Caballero soy del hambre, de la risa y la miseria.

y orgulloso de mi ensueño, de mi amor y mi poesía, soy un rey lleno de andrajos, soy hampón con hidalguía, y doliente y esforzado, todo espero y nada quiero, porque el hambre y la miseria me han armado caballero.

Al mismo tiempo, confesada su adhesión al Modernismo de las sensaciones («Amo sólo de las cosas las ocultas relaciones, / quiero, más que las ideas, las extrañas sensaciones, / que el pensar es para el sabio y el sentir para el artista / en la ilógica doctrina de mi credo modernista»), el poeta, libre de las tiranías de la academia y entregado a la búsqueda de un estilo propio, se alimenta de sus ilusiones, siguiendo sin vacilar los estandartes del idealismo, seguro del triunfo.

\section{Tres poetas de la primera generación}

Con la excepción de Manuel Paso, fino poeta recordado con afecto por Juan Ramón Jiménez y muerto a principio de 1901, los escritores de la primera generación bohemia se destacaron más en la prosa que en el verso: en la novela (Sawa, Zamacois) y en diferentes géneros periodísticos (Delorme, Nakens, Bonafoux, Bark et al.), así como en el teatro con el triunfo logrado por Joaquín Dicenta (Juan José, 1895) sin olvidar el valor de sus innumerables crónicas. Otro factor tiende a dar coherencia a esta agrupación inicial: su política progresista manifestada en la Democracia social (1895) y sobre todo en Germinal (1897), así como en otras publicaciones avanzadas.

Con la muerte de Paso, víctima de los excesos de su vida noctámbula, quedaron en primer término solamente los prosistas, pero ninguna figura de la bohemia más simpática que la de Manuel Paso, silencioso y tremendo bebedor querido de todos sus compañeros. Su exigua obra está ubicada en un cruce de caminos, porque por un lado continúa el tono menor e intimista heredado de Bécquer (la primera edición de Nieblas, su único libro de poemas, es de 1886) y, por otro, redactor de Germinal e íntimo amigo de Dicenta con quien colabora en obras para el teatro, se asoma en los últimos años a una experiencia inspirada en las circunstancias sociales del país. En la mejor poesía del incorregible bohemio, sencilla y altamente subjetiva, a la cual no falta algún recuerdo rítmico de la copla andaluza, se prolonga un romanticismo esencial, de 
tono pesimista y dolorido, mientras su autor se suicida lentamente en un mar de vino, tras breve vida de apenas treinta y siete años ${ }^{10}$.

Sin embargo, merecen aquí noticia otros tres poetas que cronológicamente pertenecen a la primera oleada bohemia: Pedro Barrantes (muerto en 1912), curioso personaje que figura reiteradamente en las memorias de la época; Antonio Palomero (1869-1914), poeta festivo conocido por el seudónimo de «Gil Parrado»; y, por último, Enrique Paradas (1865-1925), uno de los más destacados creadores de los cantares andaluces.

Pedro Barrantes, según algunos valenciano y para otros leonés, deseaba imitar a sus ilustres antepasados bohemios, y así creía firmemente en el alcohol como fuente de la inspiración poética. Eran motivo de risa en la época los versos que ahora transcribo de Barrantes: "iAguardiente con pólvora, soldados! / Se necesita imprescindiblemente / para entrar en la lucha denodados / con pólvora beber el aguardiente!» («Excitación al combate»). Se proponía ser un hombre tremendo e impresionar a todos con sus violentos y a menudo grotescos desplantes, pero parece que logró quedar casi siempre en ridículo. Sin embargo, a pesar de las anécdotas que se cuentan de él, no puedo menos que preguntarme si no era una figura sencillamente tragicómica o tal vez un payaso absurdo a quien debiéramos compadecer ". El que más nos dice de $\mathrm{Ba}$ -

10 Véase mi trabajo «En torno a la poesía de Manuel Paso, olvidado escritor granadino», Estudios en honor a Ricardo Gullón, Nebraska, Society of Spanish and Spanish American Studies, 1985, 263-278.

11 Emilio Carrère, en su «Perfil burlesco» (La canción de la farándula, Madrid, Renacimiento, s. s., 125-129) dice de ese absurdo y truculento personaje («un pobre hombre y un poeta terrible», 125): «Muchas veces le he encontrado vagando por el arroyo: roto, doliente, roído por la miseria. Iba sin norte y sin alma; sus «macabrerías» grotescas eran una careta para divertir o espantar a los pazguatos. En lo hondo, llevaba el dolor de su fracaso, de su vida vacía y anulada, de su trágica y cotidiana renunciación. El sentía amargamente sus lacras, su prematura vejez y su catadura burlesca de polichinela destrozado. Y comprendía la contrafortuna de sus sueños de gloria y el hórrido presente, ruin y triste, aherrojado a la pobreza, que le conducia a veces a los aposentos del palacio de la Moncloa a purgar deslices de pluma que cometieron otros. Todo por un irrisorio puñado de calderilla (127)».

El mismo texto se recoge también en La tristeza del burdel, Madrid, Imprenta de Juan Puygo, 1913, 123-128.

Otro dato: Carrère, al editar la poco conocida antología La corte de los poetas (Madrid, Librería de Pueyo, ¿1906?) incluye dos poemas de Pedro Barrantes: «Alma» y «La marcha de los vencidos». 
rrantes es Eduardo Zamacois, amigo suyo; copio una breve porción de uno de los retratos que hace el novelista de tan original personaje:

... Tuvo Barrantes una silueta inolvidable: a veces llevaba barba, lo que daba a su calva frente gravedad señorial; otras iba completamente afeitado; entonces se parecía a Baudelaire [..] Era alto, seco, de una sequedad cómica, y la costumbre de sentir oscilar el suelo bajo su pies le había dado el caminar indeciso de los sonámbulos. Hablaba bien y reposadamente, con voz sonora y una lentitud noble que le permitía vestir su pensamiento de palabras exactas y dar a cada frase su relieve debido. Su conversación atraía; tratarle era exponerse a ser su amigo [...] Ni los excesos, ni las ráfagas terribles de miseria que azotaron su espalda, ni el espanto de las noches sin cama, ni los rigores de la cárcel, donde por delitos políticos estuvo varias veces, bastaban a derribar su cuerpo avellanado. Bajo la lluvia, bajo el sol o sobre la nieve, durante muchos años Pedro Barrantes paseó su perfil raro y amable ${ }^{12}$.

Cabe añadir aquí que Barrantes era en su temprana etapa un escritor enérgicamente anticatólico y colaborador en Las Dominicales del Libre Pensamiento. Más tarde fue hombre de paja de El País, haciéndose responsable por un duro diario de los artículos peligrosos o denunciados, lo que le valía frecuentemente encarcelamientos. Esa feroz actitud anticlerical se evidencia en casi todos los poemas de su primera obra, bautizada con un título exactísimo Anatemas (Valencia, Imprenta de El Mercantil Valenciano, 1892). Esta poesía altisonante proclama un desorbitado odio a la religión, la monarquía y el despotismo. El escritor debe ser batallador y combatiente, su misión es denunciar hipocresías y estulticias de la sociedad moderna, con versos heroicos y destructores («Sombras y esperanzas»). No quiere que la amada le pida versos de dulce lirismo, ni cantar sus bellezas físicas; el poeta debe hacer vibrar su lira como el trueno, porque aún están de pie la Iglesia y el trono («Negativa»). Ataca la tiranía y el despotismo que envilecen, expresando su fe en el pueblo y su redención. Exalta la libertad y la justicia. Su profesión de fe: «No ceder por nada ni ante nadie» («A mis amigos»)». En el mismo poema, de fuerte denuncia, Barrantes afirma, si muere antes de poder llevar a cabo su obra redentora: «No permitáis que la figura negra / del cura inmundo a mi ataúd se acerque / a gruñir en latín palabras necias / sin fe y sin el respeto soberano / que deben

12 Eduardo Zamacois, Años de miseria y de risa, Madrid, Renacimiento, s.a., 218-219. En el mismo libro de memorias véase también sobre Barrantes las páginas 182-188 y 195-203. Del mismo Zamacois Un hombre que se va..., Barcelona, Editorial AHR, 1964, 188-191 y 242-244.

Para otra semblanza, véase también Pío Baroja, Desde la última vuelta del camino, I, Barcelona, Planeta, 1970, 722-725. 
inspirar las cosas muertas» (Ibidem). Siempre los clérigos, todos malvados y ruines, son blanco de sus anatemas. Sin embargo, este poeta quee no cree en Cristo ni en su iglesia afirma un tipo de panteísmo que le ennoblece cuando rinde homenaje a los misterios de la creación, siempre renovada, donde halla la obra de la mano divina ( «La plegaria eterna»).

Unos pocos años después, hacia 1894 ó 1895, se realiza la conversión de Pedro Barrantes, revelada en muchas composiciones de Tierra: y cielo (Madrid, Imprenta y Litografía del Asilo de Huérfanos, 1896): El libro en general continúa el último romanticismo español, y parecen haber sido los modelos del poeta Zorrilla y Núñez de Arce. Sin embargo, menos retórica y más lírica es la poesía de este segundo volumen, de contenido misceláneo y cuya nota más interesante es ahora la religiosa. Por ejemplo, en «Contrición» se lee:

\footnotetext{
Vuelvo por fin a tu amoroso seno, ¡Oh, Religión sagrada!

Torno a tus brazos de tristeza lleno y el alma lecerada.

¡Piedad, piedad, Señor, para el ingrato que obcecado y demente, a impulso de frenético arrebato te golpeó la frente!
}

- Así, arrepentido, pide perdón y regresa al seno de la Iglesia; han desaparecido por completo las diatribas anticlericales; y ya no ataca $\mathrm{Ba}-$ rrantes a las instituciones sociales del día. Sí canta a la mujer, a veces pura y virgen, pero la naturaleza conflictiva de algunos de estos poemas se da desde luego en el título. A pesar del tono religioso y la afirmación de la fe, no siempre triunfa el cielo en el alma atribulada del poeta («Miseria humana»); aunque busca solaz y refugio en la religión, tiene conciencia de las tentaciones pecaminosas («Fiat lux»). En esa oscilación constante entre el espíritu y la carne, el demonio y el ángel, Barrantes afirma en el poema final que no ha muerto su fe: el culto de lo divino vive en el fondo de su pecho. Ni los años ni las decepciones pueden enturbiar aquella adoración simbólica de su infancia lejana $(\ll \mathrm{Fe} »)$.

Un interés muy especial por lo macabro, ya presente en Tierra y cielo, llega a su punto culminante en la próxima colección de poemas publicada por Barrantes, cuya truculencia fundamental se revela de in- 
mediato en el título: Delirium tremens ${ }^{13}$. Sencillamente se propone ser demoníaco, cultivando temas del vicio y de la perversión, así como de los crímenes más violentos. La nota truculenta y efectista se ve en los títulos mismos de las poesías: «El verdugo y su amada», «El enterrador y yo», «La risa del diablo», «Haschís», «Inscripción de sangre» y muchos más de la misma índole. También dos hiperbólicas y monstruosas composiciones de 1905 se dedican a los asesinos Aldije y Muñoz López, ambos detenidos en la cárcel de Sevilla por su espantoso crimen ${ }^{14}$.

Exageradamente sensuales y satánicos, los versos de Delirium tremens muestran un claro cinismo y un estudiado afán de hacer estremecer al desprevenido lector. El fondo abyecto contra el cual se mueven los personajes se representa en melodramáticas escenas de borrachera, en las cuales toman parte lujuriosas mujeres y hombres igualmente degradados. Convulsivas y delirantes son las visiones macabras de Barrantes, evocadas con todo su caos espeluznante en poemas como «Dedal». Aunque están bien muertos todos los idealismos y celebran su horripilante festín los gusanos, no se pierde totalmente la preocupación por los pobres e indefensos. El poeta expresa compasión por los harapos ateridos de frío («Invernal») o los caídos que han sido rechazados por la sociedad («La marcha de los vencidos»).

La pieza del libro que más llamó la atención fue el «Soliloquio de las rameras», largo poema que narra la historia y el destino de las prostitutas obligadas a seguir una vida de vicio. Las primeras estrofas evocan esta triste trayectoria:

\footnotetext{
Nosotras somos la mundana escoria, nosotras damos el placer y el mal, ¿Viciosa juventud, ebria de gloria! iVen y disfruta el goce material!
}

13 José María de Cossío (Cincuenta años de poesía española (1850-1900), II, Madrid, Espasa-Calpe, 1960, 1315) da como aproximada fecha de publicación de la primera edición la de 1906, aunque el ilustre crítico se equivoca ligeramente en otros pormenores referidos a la bibliografía de Barrantes. Yo he manejado la segunda edición de Delirium tremens fechada en 1910 y publicada por La Libreria de Pueyo.

14 En otro lugar, Barrantes escribe «iSoy el terrible Muñoz, / el asesino feroz / que nunca se encuentra inerme, / y soy capaz de comerme / cadáveres con arroz...!», $y$, recitados estos versos ante Baroja, exclama el novelista: «Eso no tiene nada de particular [...] Y menos para un valenciano...» Y cuando Barrantes pregunta por qué, contesta Baroja «-Porque los cadáveres con arroz es lo que constituye la paella». Pío Baroja, Ob. cit., 723. 
Del cieno en la inmundicia nos hundimos;

tenemos seco y yerto el corazón;

y a nuestras propias madres maldecimos;

somos la fetidez y la abyección.

Pronto empieza el camino inevitablemente descendente. Por poco tiempo dura la belleza y todo se viene abajo:

Destruida del seno la turgencia, nuestra hermosura ya toca a su fin, $\mathrm{y}$ con ruda y glacial indiferencia nos entregamos a la chusma ruin.

Mudamos de vivienda, nuestros lechos, ya de encajes magníficos no son.

Se fijaron mezquinos los derechos; nadie puede exigir más que un jergón.

Finalmente las desafortunadas pasan a una existencia más degradada aún:

Somos bestias humanas; no sabemos

lo que es anior, decoro ni honradez, ni aprenderlo tampoco pretendemos, pues no aprendimos más que lo soez

Cuando ya no servimos para nada, nos echan del abyecto lupanar, y ya nuestra existencia degradada arrastramos sin lecho y sin hogar.

Su destino último: la enfermedad sin aliciente y la camilla miserable de algún hospital. Carrère opina, no sin razón, que el «Soliloquio» es un modelo de diatriba contra el vicio pero que no es, ni mucho menos, un modelo de poesía ${ }^{15}$. En resumidas cuentas, a Barrantes como poeta le faltan intimidad e intensidad espiritual. Sus elucubraciones y sacrilegios no convencen y no conmueven. Barrantes no pasa de ser, pues, una curiosidad, interesante dentro del cuadro que aquí se dibuja de la poesía típica de los bohemios de aquellos tiempos.

Antonio Palomero, reconocido periodista liberal que colabora en muchas prestigiosas revistas del día, merece breve noticia porque representa otra dimensión en la poesía de la época: la de poeta festivo. No es que Palomero haya tenido precisamente fama de bohemio, pero se asociaba con los escritores progresistas y frecuentaba los cafés literarios del día. Ricardo Baroja se acuerda de 1 apersona de Palomero en

Carrère, «Perfil burlesco», La canción de la farándula, 128. 
el Café de Madrid: «Un hombrecillo de edad indefinida. Lo mismo podía contar veinticinco años que cincuenta, aspecto de golfo callejero, a pesar de su decente y bien llevado undumento, rubio desteñido, gracioso y ocurrente, se distinguía de los demás por su voz de piporro profunda y ronca. Tal contradicción había entre lo desmedrado del personaje y el tono de su voz, que una frase que en otro hubiera pasado inadvertida en la conversación eran oportunas, tajantes, y producían en los contertulios hilaridad o ira.» (op. cit. 23-24).

También sobre Palomero, véase Guillermo de la Torre, «El 98 y el modernismo en sus revistas», Del 98 al barroco, Madrid, Editorial Gredos, 1969, nota 13, 28-29. Aquí se transcribe de Charivari el testimonio de Azorín según el cual Palomero, hombre desordenado que trabajaba sin método para ganarse el pan y el vino, se exaspera oyendo los elogios de la poesía delicuescente e improvisa unos versos dedicados a Valle-Inclán para probar que los hacía cualquiera. Era uno de los redactores de la Democracia social, antecesor de Germinal, y militaba siempre en la prensa avanzada. Escribía también en El País una sección permanente en verso, «La comedia humana», y José María de Cossío lo calificaba como poeta satírico y festivo «más admonitorio que descarnado y violento» ${ }^{16}$. Lo que interesa señalar es que bajo el seudónimo de «Gil Parrado», publica muchos versos humorísticos recogidos, parcialmente al menos, en el Cancionero de Gil Parrado (Madrid, Tipografía de Enrique Barea, 1900) y Versos de Gil Parrado (Madrid, Editores Saenz de Jubera Hnos., 1913).

Palomero fue un poeta de la actualidad, con el empeño de contar los hechos del día y las prácticas tradicionales de la vida española ${ }^{17}$. De

16 José María de Cossío, $O b$, cit., 823. También cita con cierta extensión el prólogo a las Coplas de Gil Parrado y recordemos las siguientes frases: «... Publicamos estas colecciones con vistas al porvenir, cediendo a los terribles impulsos de la vanidad o a la tristeza que nos produce la inutilidad de nuestro esfuerzo cotidiano... iY sentimos verdadera angustia al pensar que las frases, las observaciones y las ideas, pueden desaparecer para siempre en las aguas del Leteo! Por eso nos arrojamos a salvarlas, presentándolas de nuevo a la pública admiración (823-824)).

17 En su prólogo al Cancionero de Gil Parrado escribe Jacinto Octavio Picón: «Y claro está que, dada la muchedumbre de aspectos y fases que presenta la vida moderna, la musa inspiradora del humorismo es ese conjunto de sucesos y hechos que surgen al dia naciendo hoy para morir mañana, y que forman lo que en lenguaje periodístico se llama la actualidad (XI)». 
vivo ingenio y humor gracioso, nunca fue excesivo ni amargo. Su humor no hiere, divierte. Palomero tenía un temperamento en el fondo reflexivo, y debido a ello, su poesía rebasa la mera broma para alcanzar una dimensión más honda. De las sencillas aspiraciones de sus versos habla Palomero:

Es musa plebeya, de humildes vestidos,
que por el arroyo caminando va,
mirando la vida que por su lado pasa
y que satisface su curiosidad.

Musa de las calles, musa de la prosa que intento animarla cantando al pasar, son francas sus risas, no hay odio en su acento, su canción es fresca, tranquila, jovial.

(Cancionero)

Reconoce que la poesía ha cambiado, transformándose en una expresión más llana y más directa («Hoy la gente no hace caso / de los dioses del Parnaso / que la fantasía abona, / ni del caballo Pegaso / ni de la fuente Helicona», Cancionero «Progreso»), si se quiere más realista. Ya no hay amores castos ni gentiles trovadores para glorificarlos, y la literatura sigue el curso del llamado progreso del mundo moderno, frecuente blanco de su sátira y buen humor. Gil Parrado, desde luego, no toma muy en serio ciertas cosas, y de modo especial somete a juicio irónico las ciencias contemporáneas. Le duele mucho que a pesar de los innegables adelantos la Medicina no se haya inventado una inyección capaz de curar la política. Claro que a menudo satiriza a los políticos («ilustres camaleones», Cancionero, «Viendo a Frégoli»), y en otro lugar cuenta cómo un político recorre su distrito electoral en defensa de una idea que no le importa un pito, y que prepara toda su campaña evocando a la España legendaria para así mejor mover opiniones (Versos, « A la lucha!»). Rechaza Palomero por supuesto la patriotería retórica, aunque sí está preocupado de veras por la pésima situación de España (Cancionero, «El país del abanico», poema en que recomienda como remedio menos charlar y más trabajo).

En otra ocasión, el zumbido de una mosca interrumpe la tarea del escritor apurado por su trabajo de periodista a rendir homenaje a la actualidad momentánea. Palomero describe ese instante poco inspirado de la siguiente manera:

Más, ¿qué es esto, picarilla? 
La mosca, sin comprimirse, dejó sobre una cuartilla

lo que no puede decirse.

Nada; un punto, su tarjeta, clara expresión de su juicio...

¡La señal justa y discreta

de su aprecio por mi oficio!

(Versos, «La mosca»)

Y si no una mosca es un humilde grillo, cuya canción distrae al poeta en el momento sublime de la creación. Se resigna porque todos cantan con la voz que Dios les ha dado: "Y hay también muchos cantores, / pobres y vanidosillos, / que la dan de ruiseñores, / y cantan como los grillos (Versos, "Un grillo")». Aun al acercarse a los temas más abstractos no puede Gil Parrado refrenar su actitud humorística y hasta irreverente (Versos, «Al tiempo»). Aunque persona de carácter evidentemente escéptico, Palomero canta las eternas necedades del hombre y hasta cierto punto es indulgente ante las debilidades humanas. No pierde jamás su sonrisa jovial, y su espíritu crítico, aunque a ratos triste, carece de notas amargas. Protesta con las armas de un sano humorismo, y su modesta aspiración es cantar, derrochando más alegrías que pesares (Versos, «Autorretrato»). Deliciosa es su auto-ironía.

A esta primera generación de bohemios pertenece otro escritor de tipo muy diferente, cuya obra no merce el olvido casi total en que ha caído. Me refiero a Enrique Paradas (1865-1925), de vida novelesca, que era fecundo poeta. Como bien se sabe, Paradas fue muy amigo de los Machado y, juntos los tres, hicieron a fines del siglo la revista satírica La caricatura (1892-1893). Aurora de Albornoz ha reproducido los textos de Antonio (no los de Manuel) y los que se escribieron en colaboración en esta publicación, por lo visto dirigida por Paradas ${ }^{18}$.

Aurora de Albornoz, La prehistoria de Antonio Machado, Puerto Rico, Ediciones de La Torre, 1961. Es lástima que no haya hablado más en su breve presentación de los textos acerca de Paradas, porque son escasos los informes sobre él al alcance del investigador.

Sobre el mismo tema, véase Miguel Pérez Ferrero, Vida de Antonio Machado y Manuel, Col. Austral 1135, Buenos Aires, Espasa-Calpe, 1952, 41-42, que da algunos datos más sobre la vida pintoresca de Paradas. A última hora, gracias a Ricardo Gullón, he podido leer los dos artículos que Manuel Machado dedica a la vida y obra de su exaltado amigo, textos publicados en Arriba (26 de octubre y 16 de noviembre de 1941). Comienza el retrato del siempre inquieto Paradas con el siguiente párrafo: «El poeta Enrique Paradas era, después de todo, como la Vida: 
También se recordará que Paradas y Manuel Machado colaboraron en dos libros tempranos (Tristes $y$ alegres, 1894 y Etcétera, 1895) ${ }^{19}$. Años después, en su discurso académico leído en 1936, Manuel Machado, con evidente afecto, expresa grandes elogios de su amigo:

Enrique Paradas fue, sin duda, el mejor autor de cantares que ha habido en España. Millonario a los veinte años; cochero de punta... a los veinticinco. Y luego, nada y todo: cómico, maestro de escuela, comisionista, fotógrafo ambulante... Cuando yo lo conocí [...] estaba de partiquiño en la compañía del Teatro Español. Con un poco de paciencia habría resultado un actor excelente [...]. Y esto ocurrió a Paradas, cuyas coplas, en su mayoría, fueron a parar al mar de la poesía popular. Y no encontraron, sino pocas - ioh, crítica española! - un pescador que de allí las sacase para reivindicar el nombre de su autor... ${ }^{20}$.

Por su parte, Antonio Machado cita la siguiente copla de Paradas:

El hombre, para ser hombre

necesita haber vivido,

algo sorprendente, ilógico, disparatado, fluente, cambiante, contradictorio, vulgar y maravilloso al mismo tiempo, sin atadero ni sentido apreciable. Y siempre en marcha...) En efecto, su vida era movimiento constante (alguien lo llamaba por eso Corrientes), totalmente sin sentido común e irreflexiva. Había derrochado una fortuna - afirma machado - pero quería ganar dinero por los más absurdos y extraordinarios caminos. Era todo lo contrario de un hombre de letras; no le importaba tampoco la gloria; y la publicación de un libro (vendía ejemplares yendo de casa en casa) representaba una momentánea tregua en los frecuentes periodos de extremada indigencia. Cochero en provincia, actor en la capital. Abandonado el teatro, quedó nuevamente «a la clemencia divina, con el día y la noche por todo capital».

Machado cita varios cantares de Agonías, libro del cual el viejo Campoamor había comprado siete ejemplares para ayudar económicamente a Paradas, y reproduzco uno de ellos: «No encuentro vino en el mundo / que se suba a mi cabeza. / Como el aceite en el agua / así flotan mis tristezas». Rehuía siempre la publicidad y totalmente ignorado logró, paradógicamente, la gloria de ser sentido y comprendido.

Tras las clases de latín proporcionadas por Benot y el fracaso del negocio de La Caricatura, se esfumó la única seguridad que tenía Paradas, quien se marchó de la Corte recorriendo «media España como anticuario o trapero, fotógrafo ambulante y librero de viejo». De tiempo en tiempo venía a Madrid, enriquecido el caudal de cantares pero empobrecida pronta la bolsa volvía a marcharse. Al levantar su librería de Cádiz, nos diche Machado, regresa a Madrid con la idea de instalarse definitivamente, pero fatigado por tantas correrías, pronto murió al cumplir sesenta años. Eso, pues, en 1925.

19 Sobre la temprana poesía de Manuel Machado, véase mi artículo «Los comienzos de Manuel Machado», Revista de Archivos, Bibliotecas y Museos, núm. 1, enero-marzo de 1975.

Manuel Machado, Unos versos, un alma y una época, 48 y 50. 
haber dormido en la calle

$y$, a veces, no haber comido ${ }^{21}$.

Y luego añade un comentario que no tiene desperdicio:

... Yo no sé si esto es poesía, ni me importa saberlo en este caso. La copla -un documento sincero de alma española - me encanta por su ingenuidad. En ella se define la hombría por la experiencia de la vida, la cual, a su vez, se revela por una indigencia que implica el riesgo de perderla. $Y$ este a veces, tan desvergonzadamente prosaico, me parece la perla de la copla. Por él injerta el poeta - jcon cuanta modestia! - su experiencia individual en la canción, lo que algún día llamaremos - horripilantemente - la vivencia del hambre, sin la cual la copla no se hubiera escrito.

El primer libro de Paradas que he manejado directamente (hubo otro anterior, Agonías de 1891) es Undulaciones (Madrid, Imp. de El Secretariado, 1893), volumen dedicado al venerable amigo de los tres escritores Eduardo Benot, a cuya tertulia solían asistir con regularidad. Se añade al libro un epílogo de Manuel Machado («Post Scriptum», 179-189). En estas páginas finales Machado se refiere de manera especial a los cantares, que estima de lo más hermoso del libro, e insiste en la dificultad de conseguir la genuina nota popular, así como la sencillez y espontaneidad del pueblo. Ese género no se imita, dice, y no se han hecho estos versos en las bibliotecas. Paradas tiene una fabulosa aptitud para el género de los cantares, y ahora insiste Machado:

... No es el imitador de la poesía popular; no el vate que estudia las maneras del pueblo para asemejársele mediante una labor concienzuda y penosa; no es tampoco el que con usar un lenguaje pobre y grosero cree haber vencido la dificultad del cantar; olvidando que las más felices expresiones de los más profundos sentimientos se encuentran en las poesías populares; lejos de todo eso, Enrique Paradas es el identificado por completo [...] espontáneo en la expresión del sentimiento, exacto en las comparaciones, vivo en las imágenes, rápido y conciso en la expresión, fecundo como la musa popular y como ella elocuente (180-181).

En Undulaciones hay también muchos poemas inspirados en la risueña y pródiga naturaleza de Andalucía, con toda su luz y color ( «Ya amanece», «Luz y sombra», «Sevilla»), y Paradas exalta el paisaje primaveral de su tierra natal, así como las bellezas morenas («Mayo andaluz»). Tampoco faltan los motivos taurinos y todo lo más típico del ambiente andaluz, así como el sentimiento de la pena y el llanto («Allí»). Machado, por su parte, elogia la composición «Ultima voluntad», en

21 Antonio Machado, Juan de Mairena, I, Buenos Aires, Losada, 1942, 173. 
que el poeta pide a la amada que no ultraje el recuerdo del hombre que tanto la había querido.

De los cantares, que expresan con una gran economía de recursos los temas característicos de la pena y la soledad, algunos son verdaderos hallazgos, lo que dificulta la selección de ejemplos:

En silencio te he querido

y en silencio te querré:

Lo sabes, niña, lo triste

que es en silencio querer!
Tienes tan blanco tu seno

como graciosa la cara,

y el cabello tan dorado

como negras las entrañas.

En las seguidillas se acentúan las notas fatídicas, ahora más intensamente amargas, $y$, junto con un sufrimiento más agudo, se impone el frío de la muerte. Tampoco falta el tema de la maldad de los hombres y del mundo en los cantares de tono filosófico:

\author{
Hay ojos que enfrían; \\ Hay ojos que encantan; \\ tus ojos, morena, calientan de un modo \\ que encienden y matan. \\ Perdí la tristeza \\ y hallé la salud, \\ en aquellos ojazos tan negros \\ que dan tanta luz.
}

\author{
No quiero consuelos \\ que ha muerto mi madre: \\ ¡el dolor que yo siento en el alma \\ no lo alivia nadie! \\ Es triste la cárcel, \\ triste el hospital; \\ pero aún es más triste vivir en el mundo \\ de la caridad.
}

Al año siguiente, como ya se dijo, aparece el libro Tristes y alegres escrito en colaboración con Manuel Machado, y ahora solamente me conciernen las páginas de Paradas. Sin embargo, en el volumen de 1894 se publica una breve contera de cuatro páginas de Salvador Rueda, y quisiera agregar que Machado por su parte aporta unos diecisiete cantares y otras coplas populares (cuatro soleares). En el aludido epílogo Rueda elogia los cantos del pueblo y cita con abundancia otras coplas («la historia entera de una raza»), definiendo el género como «mariposa de cuatro alas»». Ocupándose de los textos de Machado y Paradas, reproduce algunos de los que más le han llamado la atención y luego pregunta: « ¿No le parecen al lector estos cantares de lo mejor que en España se ha producido en su clase? ¿Y no es cierto también que esto vale infinitamente más que los millares de odas huecas y versos arquitectónicos y limados, de que tanto se ha abusado por los vates de paciencia china?» Como ha de esperarse, son los cantares de Paradas (setenta y cuatro en total) las composiciones de mayor interés y sobre ellas escribe Cossío: «... su carácter popular tiene una autenticidad verdadera, y más meritoria y si cabe decirlo más auténtica, porque no son imi- 
taciones o transcripciones que pretenden una identidad con las coplas del pueblo en carácter, en tono o en lenguaje, sino una depuración de los rasgos más selectos y significativos de tales cantares» ${ }^{22}$. Que valgan como otros ejemplos de la capacidad que tenía Paradas en este tipo de poesía concisa y sobria:

Compadéceme, gitana, que quisiera darte un mundo y no puedo darte nada.
Mas triste voy que un sepulcro,
rodando por esas calles,
y andando por esos mundos.

Te pasas la vida como la moneda, sin querer a nadie, de una mano en otra, rueda que te rueda.

En estos poemitas se ha logrado la autenticidad a que se refiere Cossío, feliz en el concepto y en su expresión. Encuentro poco interés en los otros poemas del libro, que en general continúan la vena andaluza, aunque la nota entre humorista y sarcástica es a menudo más aguda. Sin embargo, como advierte Cossío ${ }^{23}$, uno tiene la sensación de que algunos versos son en realidad un cantar en ciernes: «Vivo para cumplir la penitencia / que quieren pronunciar tus labios rojos, / para llorar rigores de tu ausencia, / para dormir soñando con tus ojos.»)

Por último, en 1913, Paradas publica otro libro de poesía titulado Impresiones. Cantares (Madrid, Imprenta Helénica), que se inicia con un autorretrato del cual reproduzco algunos versos, que revelan su carácter bohemio, así como la inevitable dispersión en su vida: «Tantas cosas quise ser, / tantas cosas he emprendido / que al cabo no he sido nada, / pues ninguna he concluido. / La independencia es mi anhelo, / vivir según mi capricho; / ni mandar ni obedecer, / ni ser yunque ni martillo». A mi modo de ver, los versos del nuevo volumen tienden a hacerse más sentenciosos, con mengua de los pocos momentos de verdadero lirismo. Poesía admonitoria e ingeniosa expresada en fragmentos sin desarrollo, a menudo de indiferencia sarcástica. Paradas, escéptico y decepcionado, ha vivido mucho y ha luchado, expresando su cansancio espiritual en virtud de la monotonía de una existencia ingrata. Esos momentos de engaño y de tristeza que le acompañan en el presente se representan en los siguientes versos decepcionados:

Ibidem, 497. 
En el libro de la vida he aprendido lo que sé, por él he sabido cosas que no quisiera saber.

¿Qué vale el dinero?

El dinero se va y viene: la vida es lo que perdemos.
Las olas buscan la playa; las olas vuelven al mar, también quiero yo dejarte y no te puedo dejar.

No me mires en el templo; no me hagas estar pecando y rezar al mismo tiempo.

\section{Tres poetas de la segunda generación}

Príncipe de los poetas bohemios es Emilio Carrère (1881-1947), autor de una abundante obra y figura significativa del mundo literario de Madrid durante más de veinticinco años. No era un tipo excesivo, gesticulante y teatral como su antepasado Alejandro Sawa, quien murió en 1909, el mismo año en que apareció El caballero de la muerte, quizá la obra en verso más característica de Carrère. Entregado totalmente a la vida noctámbula, se le veía en las viejas calles y cafés de la ciudad, acompañado muchas veces por Corbalán u Ortiz de Pinedo, vestido de chambergo, capa y chalina. Señal de rebeldía y compañera de su juventud era su capa andrajosa («La capa de la bohemia») y tampoco faltaba la vieja pipa, que representa como la capa la historia de su vida («La pipa»).

Mucho se ha escrito sobre la persona y la obra de Carrère. En general las semblanzas son simpáticas, aunque no carece de detractores que le acusaban de farsante ${ }^{24}$. $\mathrm{Al}$ hablar de Carrère importa consignar dos cosas importantes de mayor alcance que los datos de su vida anecdótica. Primero, sabía diferenciar entre hampa y bohemia. Por cierto, no sufría del pecado de la pereza, como atestigua su extensa obra, aunque en la época se le llamaba «rey del refrito», puesto que repetía páginas publicadas ya en otros distintos lugares. Por lo tanto, es poco menos que imposible establecer con rigor una cronología bibliográfica de Carrère, quien además dejó sin recoger cientos de páginas diseminadas en la prensa. Segundo, tenía fama de alentar generosamente a los jóvenes que intentaban publicar sus primicias. Y, junto con Gómez de la Serna y Cansinos-Assens, fue durante un tiempo innegable centro de

Además de la simpática semblanza trazada por Gómez de la Serna, citada en la primera parte del presente trabajo, quisiera recordar otras páginas que completan el retrato del escritor: César González Ruano, Siluetas de escritores contemporáneos, Madrid, Editora Nacional, 1949, 123-127. 
una porción de la vida literaria de Madrid. Tenía su sede principal de operaciones en el Café de Varela aunque frecuentaba mucho el Café Regina Victoria, donde otros bohemios como Buscarini, Villegas Estrada y todos los de la corte le rodeaban.

En aquellos tiempos - y hablamos del segundo decenio del siglono es exagerado afirmar que Carrère fue el poeta español más leído y más admirado. Es tal vez difícil de entender hoy aquella popularidad, porque ya no se habla mucho de él, prácticamente olvidado por muchas razones, inclusive la grandeza de otros poetas mucho más selectos (Machado y Juan Ramón desde luego), así como los de 1927 que siguieron a los maestros citados. Sin embargo, hay varios factores que ayudan a explicar la acogida entusiasta que recibe Carrère. En primer lugar, publicaba en periódicos y revistas de gran circulación y al alcance de todo el mundo ${ }^{25}$. Además su poesía, de una pegadiza musicalidad todavía modernista, no exigía gran esfuerzo para ser entendida, y de modo especial el lector mediano podía identificarse con algunos de sus temas más visibles, en el fondo románticos y hasta sentimentales. No me refiero sólo a los aguafuertes de la mala vida madrileña, sino también a los cuadros históricos de la ciudad y otros lugares del país. Hacía sus poemas, pues, sobre realidades conocidas por numerosos lectores, y les ofrecía nuevas perspectivas en una insinuante lengua musical. En efecto, sería difícil negar que los siguientes versos no tendrían cierto atractivo para el lector no muy exigente de aquel entonces:

\footnotetext{
Mi amada es una pálida belleza de marfil.

La Luna, la maligna Luna, fue su madrina, y ha puesto en su semblante la palidez divina y triste de las lunas idilicas de abril.

Tiene en sus ojos glaucos un beleño sutil y fosfórico; una fascinación felina, el beso emponzoñado de la extraña madrina. Es luminoso y triste su rostro de marfil.
}

(«Flor de locura»)

Otro tanto podría decirse de la muy conocida composición «Musa del arroyo», cuyos primeros versos se transcriben ahora: «Cruzábamos

25 Enrique Díez Canedo («Provincia, Bohemia, Hampa», Estudios de poesía española, México, 1965, 95-102) advierte que por extraña paradoja Carrère fue bien recibido como colaborador en los seminarios gráficos y en las revistas más burguesas (98-99). Entre paréntesis, y como mera curiosidad, Díez Canedo es autor de un poema titulado «Bohemia» que se incluye en La corte de los poetas, antología editada por Carrère a principios del siglo. 
tristemente / las calles llenas de luna, / y el hambre bailaba una / zarabanda en nuestra mente. / Al verla triste y dolida / yo la besaba en la boca. / ¿Por qué aborreces la vida, / Risa Loca? / No llores, rosa carnal, / que yo robaré el tesoro / de la tiara papal / para tus cabellos de oro». Cabe añadir que los temas de la bohemia literaria siempre atraían a un sector del público y apelaban a la rebeldía idealista de que todos tenemos un poco. Cuando en el poema «Un bohemio. Perfil de aguafuerte) Carrère evoca al bohemio típico, muchos lectores sin duda se sentirían fascinados por el aventurado destino de este mártir del arte. Tres notas entonces aseguraron el triunfo de Carrère: una especie de nostalgia por un pasado, personal y heroico, visto en las vetustas plazas y calles bajo el sortilegio de la luna; la creación de un ambiente verleniano y prohibido, junto con una marcada compasión por los náufragos de la sociedad; y todo un registro de tópicos fundamentalmente románticos frente a la vida aburguesada de todos los días. En fin, la poesía de Carrère, si bien exalta la miseria y se nutre de lo lúgubre, tiene hasta hoy un encanto no totalmente extinguido ${ }^{26}$.

Indudablemente los versos bohemios son los mejores y más característicos de Carrère ${ }^{27}$, y en virtud del tema de las presentes páginas pienso concentrarme en estos poemas sin desdeñar otros aspectos de su obra poética. El primer libro en verso de Carrère se titula Románticas (Madrid, Imprenta de la Prensa, 1902), con un prólogo en verso de J. Ortiz de Pinedo, amigo inseparable del autor en aquel entonces. Se trata de una poesía caracterizada ya en el título, algo juvenil e ingenua,

26 Cansinos-Assens, a quien no le gustaba la persona de Carrère, se pregunta a qué se debe esa popularidad de una labor poco original y poco renovadora que por cierto no atrae por su simpatía y que exalta la fealdad. Según Cansinos esa difusión corresponde «... a la multiplicidad de elementos ajenos que ha acogido en su obra, prestándose sucesivamente a todas las modas literaria, tan cambiantes como las femeninas [...] Su obra es un mosaico de todo lo que ha gustado.una vez [...](204). Carrère es, pues, un escritor libresco, es decir, formado en los libros, y en esto quizá estribe su valor y su secreto de difusión [...](209). Circunstancias casuales, una más asidua colaboración en las revistas ilustradas, esas revistas que no faltan en las peluquerías, un género de vida más callejero y más anecdótico, sin el retraimiento sacro de un Juan Ramón, ni las sacras soledades de un A. Machado, le han convertido en el portaestandarte más visible y en el momentáneo sustentáculo de tendencias literarias que no tuvieron en él su origen, Carrère es hoy el faro de fascinación para los noveles..." (212-213), La nueva literatura, I, 201-213.

27 Así lo afirma también José María de Cossío al editar una antología popular de la poesía de Carrère (Antología poética, Col. Austral 891, Buenos Aires, 1949, 11), aunque se incluyen muestras de otros aspectos de su lírica. 
de tono claramente becqueriano. La aparente influencia de Bécquer se revela no sólo en los temas románticos en sordina, sino también en la versificación y las rimas asonantes. No hay nada en todo el libro que preludie al escritor posterior a menos que sea el último poema del libro ( «iCantad, obreros!»), que exalta el trabajo y vaticina la resurrección de España por los brazos del humilde obrero. Como he dicho ya, la consagración del poeta y la conquista de su verdadera personalidad se logran en EI caballero de la muerte (1909). Afiliado ya a un Modernismo formal e integrados los temas bohemios, Carrère publica en los próximos años una larga serie de títulos de libros en verso.

Para empezar el estudio de la poesía de Carrère no hay nadie que mejor defina su modo de ser que el mismo poeta en sus frecuentes composiciones autobiográficas. En esos autorretratos habla de sus dolores y sus penas, de sus aspiraciones y fracasos. Basta citar un solo ejemplo:

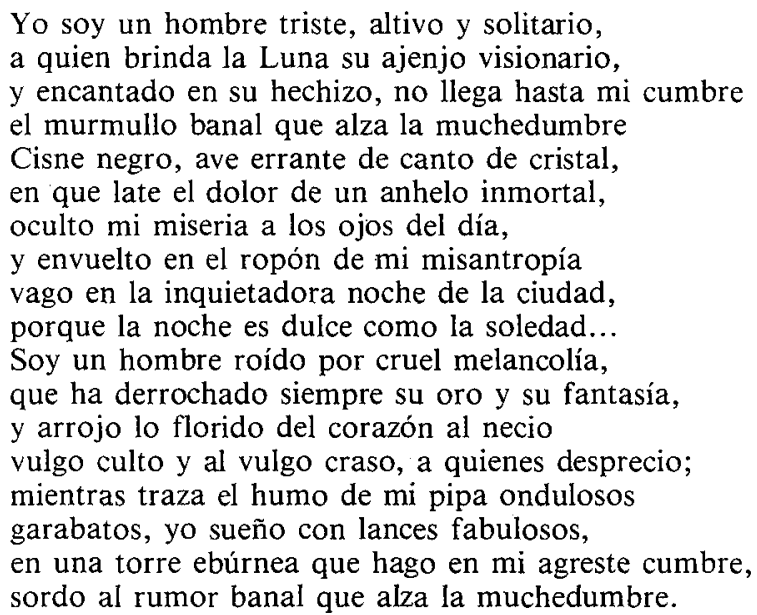

(El caballero de la muerte, «Pórtico»)

Afirmada su postura superior, en otro lugar le duele que la gente sólo perciba en él lo pintoresco sin darse cuenta de sus hondas angustias y de la tragicomedia de su vida irrisoria (Del amor, del dolor y del misterio, «Prólogo»). En la composición «La hora negra», publicada en La canción de las horas, el segundo cuarteto dice: «La araña gris del tedio hila en mi corazón. / ¿Con qué llenar el negro vacío de la vida / cuando graznan los cuervos de la desolación, / y el alma está en tinieblas y la carne podrida?». Con frecuencia, sin embargo, Carrère se acuerda de un pasado menos duro, más apacible y tranquilo, en 
su «Cancionero de ayer» (Dietario sentimental) y los «Sonetos del buen ayer» (Del amor, del dolor y del misterio).

El poeta se enternece ante el espectáculo del dolor universal que percibe a su alrededor, y siente una profunda compasión por los mendigos y los leprosos, por toda la procesión macabra de los pobres y desdichados de la sociedad moderna. Es, pues, poeta oficial de las grisetas, ahora lastimosamente transformadas en rameras esqueléticas y pintadas («Elogio de las rameras»). Igual compasión experimenta por los que duermen en los jardines nocturnos de la ciudad, donde poetas y mujeres venidas a menos, vacías las horas sin que nadie los espere, cuentan sus cuitas («Los jardines de la noche»). Junto con su amor por los viejos barrios y plazas de Madrid (el poema «Barrio latino matritense» es explícito), tantas veces evocados con singular fortuna, y los cafés frecuentados por los bajos fondos de la sociedad («El café de San Millán», «Lienzos madrileños», «El viejo figón», «Café de artistas»), Carrère recrea en sus versos otros escenarios más crueles y sórdidos como los de lupanar y de buhardilla. Una síntesis eficaz del vicio y de los placeres prohibidos es la poesía «El dolor de la noche» y del hospital, destino de tantos, escribe: « ¿Dolor de Hospital: ¡La materia podrida / y el alma destrozada de angustias eternales! / Nunca es más cruel el tiempo y más lenta la vida / que en los relojes de los hospitales. / Olor de medicinas y hedor de calentura, / clama el dolor humano en hirviente montón; / en cada lecho, un número, sin piedad, sin ternura. / El hospital nos mata de frío el corazón» (El caballero de la muerte, «El hospital»); y hasta evoca el perverso ambiente aristocrático de la casa de juego ( $« \mathrm{Am}$ biente», «Las simas»).

Carrère practica una bohemia literaria más o menos decorosa, lejos del hampa, pero en su «Espístola a Joaquín Dicenta» recuerda un pasado en que el gran bohemio (artista, valiente, bebedor y sensual) vivía tiempos más gloriosos en que cantaba el pájaro azul del ideal. Ahora ya no existen - sigue diciendo Carrère - la misma juventud y rebeldía: los tiempos son otros y el momento actual, «hipócrita y bestial, mezquino y violento», está dominado por los falsos oradores retóricos, que influyen en un pueblo ignorante e indiferente, más interesado en los toros que en el arte. De cuando en cuando también se encuentra en su poesía un apunte real de la bohemia española de la época. Por ejemplo, en la poesía «Viejos cafés» hay una estampa en que aparecen Valle, Azorín, Bargiela, Godoy, Bello y Dora la modelo, cada uno evoca 
do con su atributo más característico. Uno de los poemas más citados de Carrère en el presente contexto es su «Oración a la bohemia», obra que resume los ideales de la secta:

Por vosotros, príncipes de andrajos y rimas,
líricas alondras de las altas cimas
que dora la Gloria, el Arte, el Amor.
Por vosotros, pálidos hampones vencidos,
con un óleo santo de ideal ungidos.
Yo quiero rezar por vuestro dolor.
$\ldots \ldots \ldots \ldots \ldots \ldots \ldots \ldots \ldots \ldots . \ldots \ldots$
Pálidos troveros, de gachos sombreros,
que en el alma llevan, cual santos luceros,
en verso divino y un ritmo inmortal,
los que por la vida marchan deslumbrados
porque tienen siempre los ojos cegados
por un milagroso jirón de ideal.
Por los sin ventura que nunca tuvieron
la llave de oro de la inspiración;
por los que no triunfan, por los que murieron...
Por vosotros quiero decir mi oración.

Vista la importancia que ocupa la bohemia en los poemas de Carrère, hay otro aspecto significativo de su obra que merecería más serio estudio del que ahora le puedo dar: los motivos sobrenaturales de la superstición y del maleficio. Carrère es poeta lunático y siempre demostró un gusto especial por lo lúgubre y lo espantoso; se recreaba en la pestilencia, percibiendo en la muerte una presencia física, amén de sus aspectos más grotescos y repugnantes. En esto hay cierto medievalismo arcaico que lo relaciona estrechamente con una porción de la obra de Valle-Inclán, y a la vez, en ambos escritores, su visión abarca no sólo una atmósfera de brujería sino también la de otras vidas ultramundanales. Esa filiación con el pensamiento esotérico compartido con casi todos los modernistas se revela con toda claridad en algunas de sus meditaciones nocturnas ( La noche en la ciudad»). Los dos tercetos del soneto «Maleficio», cuyo tono no está muy alejado tampoco de ciertas composiciones de Valle, sirven para dar remate a estas páginas sobre la persona de Carrère.:

Mi vida está influida por cruel maleficio;

el amor es lujuria; la poesía, oficio;

las cosas nobles pierden su augusta dignidad.

Los pecados me roen lo mismo que gusanos, y ruedo a los embates de poderes arcanos como un polichinela de la Fatalidad. 
Tal vez el más hondo y auténtico poeta de los cenáculos bohemios en las primeras décadas del siglo fuera el murciano Eliodoro Puche (1887), así, sin hache, a quien dedica unas páginas críticas CansinosAssens ${ }^{28}$. Puche frecuentaba las tertulias de éste y de Gómez de la Serna, figurando asimismo en las memorias de la época ${ }^{29}$. Excelentes son los retratos de Puche que nos han dejado González Ruano y Cansinos. El primero, que lo admiró como poeta superior a otros epígonos del Modernismo, destaca su aspecto siniestro y su modo humilde de vestir, así como su costumbre de ser cliente de las tabernas criminales y ser amigo de las mozas de la baja prostitución. Enfermo y borracho, sólo quería beber y vagar por Madrid, sin molestar a nadie. González Ruano cuenta también que estuvo algún tiempo en la cárcel y mientras tanto heredó una gran fortuna ${ }^{30}$. Por su parte, Cansinos insiste en el completo desaliño y suciedad de la indumentaria de Puche, quien siempre se vestía de negro, y de ahí la comparación con un ataúd puesto de pie, y continúa diciendo: «Se desayuna con morapio y empieza el día, mejor dicho, la noche, ya borracho» ${ }^{31}$. También en otro lugar el mismo Cansinos, al encararse más directamente con su obra, recuerda al escritor misántropo («duro y agrio», «rebelde y arbitrario», «adusto y si-

28 La nueva literatura, II, Madrid, Sanz Calleja, 1925, 311-323. El mismo texto sirve de prólogo para el segundo libro de Puche Corazón de la noche, Madrid, Tipografía Yagues, s. a., ¿1918?, VII-XVI. Se completa la bibliografía del poeta con otros dos títulos: Libro de los elogios galantes y los crepúsculos de otoño y Motivos líricos, ambos libros publicados en Madrid en 1917. Además Puche fue traductor de Verlaine y tres tomos de prosa del poeta francés le correspondian en las Ediciones Mundo Latino: Volúmenes III (1921), VI (1923) y IX (1923). Sobre Puche (quien creía que por ser borracho tenía derecho a ser traductor privilegiado de Verlaine) y el Mundo Latino véase Cansinos-Assens, "La lenta agonía de Mundo Latino», La novela de un literato, II, Madrid, Alianza Editorial, 1985, 351-363 y especialmente las páginas 354-355.

29 Ramón Gómez de la Serna (Nuevos retratos contemporáneos, Buenos Aires, Editorial Sudamericana, 1945) recoge el poema de Alfonso Camín titulado «Tertulia de Cansinos" (305-308).

Hay en la edición de 1918 de Pombo (Imprenta Mesón de Paños, sin paginación) una breve referencia a Eliodoro Puche como «poeta interesante de alma verdadera e intensa, amigo de la borrachera y de la noche».

3) César González Ruano, Memorias: mi medio siglo se confiesa a medias, Madrid, Tebas, 1979, 233-234. Del mismo hay otros comentarios similares en su Antología de poetas españoles contemporáneos, Barcelona, Editorial Gustavo Gili, S. A., 1946, 205.

31 Cansinos-Assens, La novela de un literato, II, 113-114. 
lencioso», "próximo y ajeno»), aislado de los demás y perdido en sus ensueños de inefable poesía. A pesar de los inevitables acentos nocturnos de Musset, Baudelaire y Carrère que suenan en sus versos, el alma verdadera del poeta es, según Cansinos, sencilla e ingenua ${ }^{32}$.

Corazón de la noche (Madrid, Tipografía Yagues, s. a.), único volumen de Puche que he podido conocer directamente, se dedica a los poetas Antonio Machado, Juan Ramón Jiménez y Enrique de Mesa. Es un hermoso libro, notable a mi juicio por su gran potencia afectiva. Puche es, como tantas veces se ha repetido, poeta nocturno y poeta de la noche («Invocación al canto de la noche»). La fuente de su emoción: un corazón que sufre y una confesada complicidad con todo lo nocturno. De ahí en parte el característico acento romántico de tan bella poesía lírica, romántica, sí, pero de un romanticismo contenido y refrenado. El poeta halla en la noche hermosura e inefable misterio, realizándose totalmente en esta belleza:

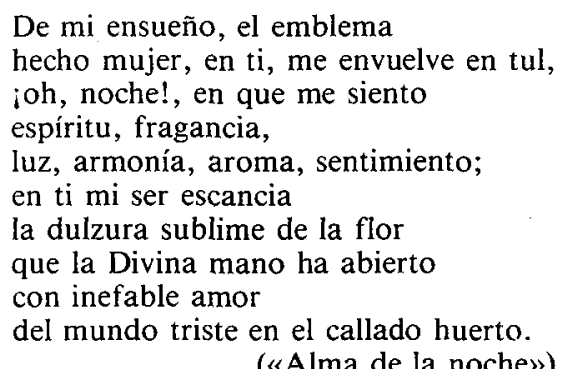

Para el poeta lunático, que de paso tiene muy poco del irónico Jules Laforgue, las horas de la noche son refugio y solaz. La noche es protectora y acompaña a los desgraciados: «Y tú, triste ramera, / y tú, borracho obsceno, / cantemos a la noche, compañera / de nuestra obscuridad y nuestro cieno. / Venid a nuestro coro / todos los miserables; / ella tiene un cendal bordado de oro / para cubrir las llagas incurables. / Ella tiende sus manos con cariño / a todo el que la ama» («Invocación al canto de la noche»). El poeta, en sus viajes solitarios por los espacios, se viste de luz lunar, lo que le brinda toda clase de favores preciosos («A veces me he sentido»), y desea flotar en el aire, despegándose de la materia. El alma atormentada de Puche establèce una estrecha fraternidad con la luna: la noche es dulce y serena, sin maleficio

La nueva literatura, II, 311-323. 
ni sobretonos diabólicos, aunque a veces fuente de embrujamiento. Pueden imaginarse fácilmente los paseos solitarios de ese soñador tan sensible a la belleza del cielo nocturno:

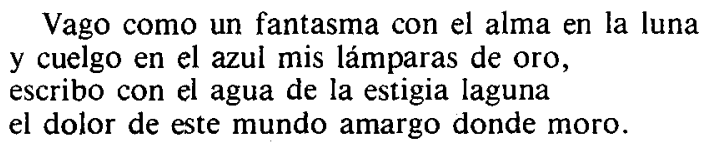

Por caminos de estrellas se dirigen mis pasos a regiones de ensueño, de ilusión y de paz, y dirijo mis versos cual piafantes pegasos por los anchos desiertos de este mundo falaz.

(«Vago como un fantasma»)

Sin embargo, las notas de paz y tranquilidad que caracterizan estas visiones siderales tienden a desaparecer cuando en otros poemas Puche se inspira en los bajos fondos de la ciudad y sus pobladores bohemios:

Ruinas de mujeres, sombras disparatadas con los ojos rasgados a manchas de pincel, los peinados postizos, las caras maquilladas, la blasfemia en los labios y en el alma la hiel.

Hace la una gala de su traje grotesco, la otra tararea una canción canalla, hay otra que acaricia a un ejemplar simiesco, un chulo, un garrotín taconeado ensaya, y unos golfos borrachos piden desde un rincón a gritos unas copas de vino peleón.

(«Café de arrabal»)

Y así, como Carrère, no olvida a las prostitutas aunque la mujer de Corazón de la noche también se idealiza, y hasta la oscuridad pasa a ser presencia femenina ("Cantos azules»). De las rameras de conciencia encanallada que no han conocido el amor verdadero habla con evidente simpatía, de todas las que dominadas por impulsos fatales of recen el cuerpo a cualquier precio («Flor de lupanar»).

No obstante, la dulzura de la noche es ofrenda de consuelo para el alma torturada del poeta, amante de la soledad («Amo la soledad»). En otro momento, envenenado por su negro pesimismo y acosado por la pena de vivir, Puche piensa en el suicidio como promesa de descanso v liberación de su calvario. Se consuela en el llanto y en la belleza de un cielo prometido, dándose cuenta con estoicismo de que la vida es sufrir hasta la muerte ( $U$ Una noche de estío»). Se pierde (o mejor se disuelve) en la noche probando sus venenos y bebiendo sus narcóticos hasta hundirse en los misterios invisibles, fracasado su intento de hallar entre 
los espejismos nocturnos «las mágicas ciudades / de mis romanticismos» («Entre las selvas negras»). Puche es un poeta que siente hondamente y ese acento afectivo, entre tierno y sensible, no está muy alejado de ciertas modalidades del temprano Juan Ramón Jiménez.

El vía crucis de otro individuo, bohemio profesional, más triste e infeliz que pintoresco, merece mencionarse brevemente: es el lamentable caso de Armando Buscarini, joven que cultivaba con poca fortuna la poesía y la prosa. Su persona inspira compasión, porque es el caso extremo de un pobre escritor sin talento, probablemente inofensivo y bueno en el fondo, que vivía en la más abyecta miseria. Su muletilla de siempre fue «¡Me voy a arrojar al Viaducto!», y una vez le aconsejó Valle-Inclán que al menos lo hiciese con elegancia ${ }^{33}$, y Cansinos cuenta un cómico intento frustrado. Según noticias dadas en las memorias es posible que haya muerto en un manicomio. González Ruano (a quien Buscarini dedica un poema) lo recuerda con cierta simpatía y refiere que vendía en las calles y los cafés sus pobres libritos (los que tengo a la vista son meros folletos baratos, de pocas páginas, y los tres llevan afecluosa dedicatoria del puño y letra del autor para «el maestro» CansinosAssens ${ }^{34}$ ). Y en su antología González Ruano imprime de Buscarini un solo poema «Hospital de leprosos», soneto en que las hermanas consuelan a los enfermos que sienten «el fuego de Vida en la carne doliente / y el frío de la Muerte dentro del corazón» ${ }^{35}$.

Para tener una idea cabal de la vida y la persona de Buscarini, hay que remitir nuevamente a González Ruano y Cansinos-Assens. Feo de

33 José Alonso, Madrid del cuplé, Madrid, 1972, 237.

34 Poseo El riesgo es el eje sublime de la vida. Poemas románticos (1923) y dos obras en prosa: Las luces de la Virgen del Puerto (¿1924?) y La cortesana del Regina (1927). En los tres casos falta pie de imprenta. Observo que Cejador anota la publicación de otros títulos (Historia de la lengua y literatura castellana, XII, Madrid, Revista del Archivo, Biblioteca y Museo, 1920, 40).

Parece que años después Hernández Cata editó, con un prólogo, un libro bien presentado que recoge los folletos anteriores de Buscarini. Tomo el dato de CansinosAssens (La novela de un literato, II, 429-430), que agrega un comentario que transcribo: «Oh, la cara de Buscarini, con sus negros ojos de vicioso, su nariz ciranesca y su boca grande, ancha, simiesca... ¿Cara de archivo policiaco! ¡Cara de adolescente pervertido, delincuente en potencia, sobre cuyos rasgos bestiales brilla, sin embargo, el celestial destello de la luz apolínea: ¡Cara de perturbado, que puede ser también la de un genio en potencia, quién sabe!... ¿No se dio esa mezcla de bien y de mal, de perversidad e inocencia, en Rimbaud y Verlaine?» (430).

35 González Ruano, Antologia, 373. 
semblante, con pelo lacio y largo, aquel hijo de amor «... conoció todas las desdichas, los tristes internados de San Juan de Dios y las duchas frías de los manicomios, el falso calorcillo de los prostíbulos ínfimos y las tremendas horas del cafetón como máximo refugio de las noches mejores» ${ }^{36}$. Por su parte Cansinos ve en el pobre poeta, víctima de burlas, una «extraña mezcla de candor angélico y de astucia diablesca», comparando sus facciones («ojos negros, grandes, estrábicos y alucinados, y sus orejas, semejantes a alas de murciélago») con las de un degenerado. Buscarini se cree poeta maldito y no deja de cultivar sus apetitos groseros en una existencia insegura e inútil ${ }^{37}$.

En las páginas que presentan sus Poemas románticos (1923, sin pie de imprenta) Buscarini, a quien le niegan colaboración en los periódicos con la excepción de La Libertad, habla en términos despectivos del mundo literario de Madrid y de sus contemporáneos. Así dice este poeta «lírico y hambriento»:

El poeta no obstante está decidido a sufrirlo todo y a morirse de hambre, que para eso es poeta y sólo da uno cada generación de vez en cuando, sépanlo todo el coro de grillos afónicos que me rodean y tienen el honor de ser mis contemporáneos que carecen de elegancia, sutileza, aristocratismo, de sentimientos, plasticidad lírica, ideología, etc., y valor para arrastrar la vida miserable de hampón; copleros absurdos, retorcedores de lugares comunes y tópicos manidos y ridículos, mixtificadores en ladrillo del sagrado sacerdocio de las bellas rimas sin ripios; que me llaman vago por la rara condición de tener talento como si no hicieran falta horas enteras para pulir el mago artificio de los versos.

Y sigue Buscarini con otras muestras de egocentrismo, insultando a los académicos, al mismo tiempo que ofrece al lector sus versos «humildes, sencillos y limpios», que los directores de periódicos le favorecen al no publicarlos entre sus bazofias farragosas.

Los temas y los personajes de Buscarini, a juzgar por lo que he podido conocer de su obra, fiel trasunto de su vida dolorosa, son los poetas bohemios despreciados y hambrientos, las vendedoras de caricias, y siempre, por encima de todo, la visión más negra y sombría del vivir. De ahí el motivo constante del suicidio. Para el poeta nostálgico, que recuerda su juventud lejana y más apacible, el camino es interminable; se siente cansado y melancólico («caminante de la vida»); sus versos año-

36 González Ruano, Memorias, 235.

37 Cansinos-Assens, La novela de un literato, II, 393-399. 
ran a la amada y son tristes soliloquios de un corazón fatigado ( $\ll \mathrm{La}$ amada ausente»); y, con dedicatoria para Manuel Machado, escribe Buscarini estos versos: «Luz de la mañana / que ahuyentas las penas: / luz en mi ventana / milagrosa hermana / de las almas buenas». El transcurrir de la vida es eterno e infinita la fatiga, gris el color predominante, y la tristeza del invierno pone sobre todas las cosas un matiz frío ( Saudades de invierno»). En efecto, todo se resume en la tercera estrofa de «El romero»: «Tener el alma cansada / y ser siempre peregrino / en el árido camino / de la jornada.» En esta poesía de la desesperación resuena continuamente la nota de despedida amorosa, sentimiento rememorado de un pasado lejano, y siempre el poeta se cruza en la vía opuesta con otras almas y otros trenes («Tren de noche»). Y finalmente esta desolada actitud ante la vida se evidencia claramente en un poema dedicado a Francisco Villegas Estrada, otro bohemio y autor del libro Café romántico y otros poemas (Madrid, 1927), y de esta composición transcribe las dos últimas estrofas:

Es una calle sin ningún viandante
jpáramo triste de silencio eterno
en donde aulla errante
algún can en las noches del invierno!
Es una calle abyecta por las miasmas
de un malsano pantano
por donde cruzan sombras de fantasmas
bajo la luna roja de verano

¿Farsante Buscarini? No lo creo del todo. De cuando en cuando se percibe un latido de sinceridad en sus exagerados lamentos, $y$, si hemos de creer en los memorialistas de la época, no puede imaginarse una vida más dura que la suya. No se puede negar que posee un temperamento exageradamente romántico y sin duda delirante. En el prólogo a la novelita Las luces de la Virgen del Puerto habla al autor de manera exacta de su modo de ser y de su terrible existencia:

... Yo soy un escritor de un temperamento romántico inadaptado al ambiente de mediocres que empestilece y denigra la vida española. Estoy sinceramente asqueado de la incomprensión de los directores de periódicos que me niegan sistemáticamente mis colaboraciones retribuidas. [...] Mis intentos de suicidio son un testimonio de la indiferencia que todos muestran a la desesperación del hombre que lucha y la prueba más clara de la falta de humanidad hacia el prójimo y el desapego de mis semejantes. Durante seis dias he permanecido en la antesala de un manicomio por reincidir en mi propósito de quitarme la vida y he tenido puesta la camisa de fuerza... 
Funesto el destino de este infeliz. Al final del breve texto de la novelita, que relata un episodio espeluznante y sangriento de un poeta bohemio que convive con los golfos de un barrio madrileño, hay un comentario («El dolor de no llegar») que firma José Romero Cuesta. Se ponen de manifiesto en este epílogo las cualidades humanas de Buscarini, persona mansa y atormentada, objeto de la indiferencia gris del ambiente. Otra víctima, pues, del calvario de un artista con poco talento en busca de un alma buena.

\section{Dos bohemios a ultranza: \\ Pedro Luis de Gálvez y Alfonso Vidal y Planas}

El malagueño Pedro Luis de Gálvez (1882-1940) era figura siniestra de la golfemia de la época, pero, además de varios relatos novelescos, escribe bastante poesía destacándose como sonetista. Para comenzar me permito reproducir un soneto autobiográfico de aquel picaro (otra versión de la misma composición se titula «El pícaro»), cínico, explotador de mujeres y célebre sablista que no vacilaba ante ninguna enormidad:
De un velón de Lucena a la luz tenebrosa leí las aventuras de Sancho y don Quijote; en Sevilla, la posta hice con Tagorote, y de yantar, un día, me dio la Gananciosa. La dueña Marialonso me ferió de la hermosa Leonora los encantos. He sido galeote, y saben mis espaldas lo que humilla el azote y mis manos ya saben lo que oprime la esposa.
De fracaso en fracaso va rodando mi suerte.
Espero resignado la hora de la muerte.
¡Qué me importan los hombres, ni la gloria, ni nada!
Por caridad, hermanos, dadme un vaso de vino y abandonadme luego en brazos del Destino, que él arrastre - isi puede! - mi existencia cansada...

Gálvez era sin duda alguna una persona tremenda y execrable, que de todo sacaba partido, y de él escribe Cansinos unos párrafos que parecen reflejar con exactitud el modo de ser de Gálvez ${ }^{38}$ :

En el mismo libro se reproducen unas cartas patéticas del mismo dirigidas a Cansinos, 343-344. 
... Es un hombre terrible, un malagueño del Perchel, capaz, teóricamente al menos, de la puñalada, y que sabe tocar todos los registros, desde el halago servil hasta la amenaza encubierta, para obtener el duro o las dos pesetas que marcan el limite de sus aspiraciones... Por su inadaptación se ha quedado en los suburbios de la literatura y sólo cuenta con la admiración de sus hampones, que se saben de memoria sus sonetos zahirientes, de un estro resentido y un corte quevedesco, redicho y amanerado... Pero lo que más le admiran es su audacia, su cinismo, las mil anécdotas pintorescas y crudas que se cuentan de él..., empezando por aquella de cuando se le murió un hijo recién nacido y lo metió en una cajita de pasas y lo paseó por los cafés, empleándolo como recurso patético para sacar unas pesetas.

A pesar de todo, el siempre generoso González Ruano afirma: «yo que le traté y aguanté mucho, sorprendí muchas veces en él un pobre corazón cargado de infinitas nostalgias ${ }^{39}$. Sobre la vida folletinesca de Gálvez - seminarista, pintor, cómico, presidiario en la cárcel de Ocaña (aquí, donde cumplía una condena de catorce años, escribió un cuento «El ciego de la flauta» premiado en el concurso de El Liberal, lo que le valía el indulto), cronista en Melilla, aventurero y soldado, hombre de cien oficios - hay una sustanciosa bibliografía que refiere las numerosas anécdotas, algunas extraordinarias y otras inventadas seguramente, de este pícaro traicionero, que se movía de café en café, en Madrid y en París, en busca de alguien a quien pegar un sablazo ${ }^{40}$.

Hasta los años veinte la obra poética de Pedro Luis de Gálvez quedó dispersa en revistas y periódicos, pero apareció en 1923 un libro de sonetos políticos titulado Buitres, censurado luego por las autoridades militares $^{41}$. En 1927 se publica en Barcelona un volumen de Poesías se-

Para otro retrato de Gálvez veáse Emilio Carrère, «El poeta andariego», El espectro de la rosa, Madrid, Mundo Latino, 1921, 80-83. En otra parte dice de él: «... Admirable ingenio, este excelso poeta, odiado, desdeñado, absurdo, fantástico, que rueda por las calles, borracho y triste, al asalto de unas pocas monedas de cobre roído, en este miserable país de la calderilla. Pedro Luis lleva una fatalidad sobre su cabeza». La copa de Verlaine, Madrid, 1918, p. 12.

También le dedica varias páginas Pio Baroja, Ob. cit., 742-746.

39) González Ruano, Antología, 202.

40 En efecto, el primer libro de Gálvez es el titulado En la cárcel (1905). Otras fuentes de consulta sobre aquel hampón de la literatura: J. López Pinillos («Pármeno»), Vidas pintorescas. Gente graciosa y gente rara, Madrid, Pueyo, 1920, 271-281; José Fernando Dicenta, La santa bohemia, Madrid, Ediciones del Centro, 1976, 128-169; y Ramón Gómez de la Serna, Nuevos retratos contemporáneos, 159-190.

41 Algunas muestras de esos textos libelistas se incluyen en el capítulo citado de $\mathrm{La}$ santa bohemia que Dicenta dedica a Gálvez, 160-162. 
leccionadas (Impresos Costa), con un retórico prólogo del bohemio Vidal y Planas, de cuya obra me ocuparé más adelante. Si el prologuista encuentra en sus versos luz y altura, oro y belleza, yo veo en cambio una poesía fuerte y desgarrada, que se regodea en el detalle macabro y a veces repugnante. Cuando Gálvez evoca las calles de la ciudad, recrea sus aspectos más displicentes, y en estos versos no pueden faltar el chulo, el borracho y el vicioso. Algunos sonetos se inspiran en el realismo de varios cuadros de Zuloaga y otras composiciones recogen impresiones de su tierra andaluza («Malagueña», «Pandereta», «Sevilla»). Sin embargo, casi todo es pobredumbre en la visión sombria y despiadada de Gálvez. Se acuerda de su niñez rebelde y triste; nuevamente se incorpora al libro un soneto autobiográfico, en que habla de sus días de seminarista, presidiario y soldado. Por donde vaya, todo es igual: una cantera de egoísmo, muda la justicia:

\footnotetext{
No me desvela el juicio de la gente.

No curo del mañana ni el presente.

Bebo para olvidar... Siempre la garra de la calumnia al cuello, sin fortuna, muerta la fe, sin ilusión alguna, y en la mano una bala, como Larra.
}

$\left(«\right.$ Ecce-Homo») ${ }^{42}$

En los siguientes versos, característicos de las normas poéticas de Gálvez, se presenta una estampa del Moulin Rouge, centro del mal y del vicio: «La música, distante... Junto a mi mesa, una / cocota ya marchita, piltrafa de hospital, / se baja, sin recato, la media: busca alguna / moneda, un luis, el precio de un pecado mortal... / Es ya tarde. Las aspas del Molino, girando / lentamente, las horas del vicio van marcando / con las cruces de fuego del humano dolor». Con decidido efectismo, en otro lugar dialoga y coquetea con la señora doña Muerte, que se le acerca vestida de novia («Canción de la Muerte»). Tal vez su actitud sombría y decepcionada ante la vida se refleja mejor en los consejos dados a su hijo nacido del pecado, y para quien presagia triste renombre: «... No seas bueno; / pon en tus labios, al besar, veneno: / el odio, como yo no ahogues en vino ("Canción de cuna")». Curiosa-

42 Otro poema («Ayer») de la misma índole se inspira directamente en su pasado, y reproduzco los tercetos finales del soneto: "Corrió triste mi infancia. Meditaba/ la abuela hacerme cura. Yo me hurtaba / del Seminario a diablear al río. / Tenía novia, Fumaba. Era valiente. / Me aburría el latín. Decía la gente: / «No harán carrera de él, ¡sale a su tío!». 
mente el libro termina con dos sonetos totalmente diferentes: el primero evoca con nada fingida ternura a la mujer que había compartido abnegd́damente con Gálvez una durísima existencia («Teresa»), y el segundo («Horas de paz») es de tranquilo tema hogareño.

En 1930 aparece otro libro de poemas titulado Negro y azul, el primer volumen de las Obras completas (Editorial Rubén Darío) de Gálvez, cuya publicación anunciaba la próxima aparición de diecisiete tomos más, proyecto que nunca se realizó que yo sepa. La presentación del libro merece alguna noticia: se abre con un fragmento hiperbólico de Ernesto López Parra acerca de la poesía de Gálvez ${ }^{43}$ y hay también una nota "adicional» (197-198), en que se dan ciertos datos sobre las composiciones del volumen, en su mayoría inéditas. Se afirma también que el libro anterior apareció con multitud de erratas; se incluyen al final unos variados juicios críticos sobre la obra literaria del autor; y Gálvez confiesa: «No soy poeta lírico (198)». Sin embargo, la dedicatoria a Teresa Espíldora (9-12) impresiona por su evidente y desnuda sinceridad en la expresión del afecto para esta mujer ya mencionada, compañera del poeta durante muchos años de vida y miseria económica. Le ofrece a Teresa sus versos y también los dibujitos de su hijo Pepito, que ilustran el libro.

A pesar de lo dicho por el autor, se ven en seguida que muchas de las poesías del libro anterior se recogen en Negro y Azul; otras se someten a modificaciones y enmiendas, a veces sustanciosas. Se repite por ejemplo, la composición «Una calle», que da la medida de algunas de lạs predilecciones expresivas y temáticas de Gálvez:

Calle mal empedrada, sucia, estrecha, torcida.

Los perros y las viejas calentándose al sol.

Una posada equívoca se ofrece en un farol.

La taberna. El barbero. - Huele a cosa podrida.

Continúan los motivos del hambre y del vino, así como las poesías hechas sobre pinturas de Zuloaga. Vuelve a afirmarse el sincero amor

43 Transcribo un fragmento del texto de López Parra: «... Gálvez es el Greco de la poesía: la forma es una compresa que vierte espumas de sangre. Tiene las pupilas vueltas del revés y se mira hacia adentro. Cada estrofa es una nota de llanto o un zarpazo de protesta. No ve la luz del sol, no puede verla, minero que pica en eterna noche la piedra de la galería para encontrar la vena maravillosa de oro. Y cuando la encuentra, ;qué rojo fulgor dantesco, qué llama de fragua interior nos envuelve, abrasándonos! (7)». Me parece innecesario todo comentario. 
a Teresa («Toda tú», «Bendito seas») y su hijo Pedro, quien vengará en la vida a su padre vapuleado («A mi hijo Pedro»). Al libro se añaden algunos retratos (Xirgu, Muñoz Seca, Blanco Fombona) y de los versos dedicados a su compañero de la bohemia sórdida Vicente del Olmo transcribo algunos: «Se mienten travesuras de su vida. / Tiene la pinta un mucho atrabilaria. / Muerden su pan, su fama y sus tacones... / Pero él oculta con pudor la herida, / y se pasa a la chusma literaria / por la cruz de sus viejos pantalones.» La serie de poemas cervantinos, iniciada con «Don Quijote» (recogido en ambos libros), se complementa con otros sonetos, «Sancho» y «Dulcinea». También figura en el reparto de personajes una ramera de nombre «Pilarín», nada codiciosa en el ejercicio de su profesión, y el poeta confiesa: «De sus senos yo hiciera mi almohada / si pudiera hacer alto en el camino, / y bebiera en su boca el último vino, / para hundirme en la Nada». Con su característico nihilismo espera felizmente a la Muerte que llamará a la puerta de la casa del poeta, traicionado y cansado, pero todavía no es la hora, dice burlonamente la Muerte. En otro poema (repetido) titulado «La calumniada» escribe: «... Amada / sea tu recia guadaña, del trabajo mellada; / y el colmillo de lobo que te asoma en la boca... / Tú, con mano segura, nos cercenas el cuello. / Gratitud infinita te debemos por ello... / Dime, piadosa Madre; y a mí, ¿cuándo me toca?». Sarcástico balance se hace de su existencia en las dos estrofas iniciales del último poema del libro:

No sé por qué tan sordo se murmura de mi honesta bohemia trashumante; no adulo al poderoso ni al danzante $\mathrm{y}$, por tanto, no vivo con holgura.

Se ha de apreciar en mí la donosura del ingenio, y el clásico talante de mi verso viril, claro, tajante, pleno de pensamiento y amargura.

( Voz en desierto»)

No menos pesimista y desconsolado es un soneto que critica duramente a la ciudad de Madrid: «Qué cansancio tan grande de este yermo país / con sus Rondas, sus vagos, su Palacio Real, / donde un pueblo borracho, sucio, que come mal, / se sujeta las bragas con el cordón de Asís...! / Trae sus modas de Londres; sus vicios, de París. / Como no tiene escuelas, alza una Catedral. / Reza y peca sin tasa. Su vida es carnaval / perpetuo. Lo gobierna pálida flor de lis». Nadie puede dudar del «realismo» directo, a menudo crudo y repelente,'de la poesía 
de Pedro Luis de Gálvez, es decir la representación de los trozos de vida real que ha vivido física y espiritualmente. Quizá sea éste el mérito principal de su obra, pero como poeta no llega a convencer sino en instantes muy contados, porque no sabe expresar toda su doliente y mísera existencia en una forma apta para conmover hondamente al lector.

A pesar de ser más conocido por sus relatos y obras teatrales que por su poesía, no puede faltar en esta galería otro enfant terrible de la vergonzosa bohemia: Alfonso Vidal y Planas (1891-1965). Más adelante, en la tercera parte de este trabajo, acerca de la novela y el teatro, se le estudia más detenidamente, pero basta por el momento consignar unos cuantos hechos. De una compleja psicología y un espíritu contradictorio, Vidal y Planas no es tan cínico como su compinche Pedro Luis de Gálvez, quien de paso lo retrata bien en un soneto del cual se citan ahora algunos versos:

\footnotetext{
No sé si es Tarragona la que ostenta la gloria de haber dado a las Letras el espíritu inquieto de este Vidal y Planas, complicado sujeto, del que yo desconozco la verdadera historia.

Su vida es una eterna ascensión ilusoria.

Tiene un grande enemigo: su despectivo reto.

(No basta escribir bien: vive el analfabeto, que da vueltas y vueltas en torno de la noria).
}

Era el caso de un bohemio lamentable, sin domicilio fijo, que vivía literalmente día y noche en el Colonial, donde por lo visto escribía su voluminosa obra. Como tantas veces hasta ahora, se deben a CansinosAssens algunos renglones interesantes sobre Vidal y Planas, exseminarista y hampón de la literatura: «... Es un joven flaco, con una cara fina, morena, en la que, bajo una cabellera alborotada, brillan unos enormes ojos negros, agrandados de fiebre y de una ansia de gloria y amor» ${ }^{44}$. Y también cuenta que Romero de Torres lo había pintado; en efecto, la novela El pobre Abel de la Cruz (1923) se publica con una lámina de este retrato. Nuestro escritor tuvo un breve momento de triunfo cuando, gracias a Gregorio Martínez Sierra, estrenó Santa Isabel de Ceres (1922), drama de burdel y de la canonización de una mujer venida a menos ${ }^{45}$. En su vida de vagabundo, además de seminarista, había si-

44

45 Cansinos-Assens, «Santa Isabel de Ceres», Ibidem, 385-389. 
do militar, golfo y escritor; de su propia existencia de detalles al hablar en una entrevista con "Pármeno» ${ }^{46}$. Escribía feroces artículos de combate y fue fundador de periódicos sumamente atrevidos (EI Loco, ESpaña Republicana, La linterna), todos de vida efímera, en los cuales atacaba en textos blasfematorios a todo el mundo. Tantas veces encarcelado por delitos políticos y no sé qué otros motivos, tuvo una vez que huir a Portugal, donde se defendió económicamente a base de otras tareas periodísticas. Total: una exagerada vida de bohemio y aventurero. Tres son sus grandes temas: la cárcel, la locura y el hampa. Por ejemplo, publica El rancho de la cárcel (Confesiones de Angel Malo) en 1914 y luego, en 1917, Tristeza de la cárcel (Confesiones de Abel de la Cruz). Salen en 1918 sus Memorias de un hampón, con un importante prólogo de Cansinos-Assens (11-23), que es un impresionante documento sobre el hampa literaria de su tiempo, en el cual se describen los horrores del famoso dormitorio de Han de Islandia, con la aparición también de algunas figuras mayores de la bohemia. Quizá cabe copiar aquí algunos renglones de la dedicatoria de tan tremendo opúsculo: «A todos los que sufren horriblemente: A los presos de las cárceles españolas. A los hampones que pernoctan en la casa de Han de Islandia. A las rameras de la calle de Ceres, que fuman tabaco malísimo, que tosen y que tienen los pechos secos como nalgas de crío tubercoloso y la mirada turbia». En el libro se imprime también el soneto de Pedro Luis de Gálvez, citado ya.

Hay, por desdicha, otro hecho capital recordado sin duda por los lectores. Fracasada su obra teatral Los gorriones del Prado (1923), sobrevino la tragedia de Vidal y Planas: el asesinato en el Teatro Eslava del conocido escritor Luis Antón de Olmet por razones sentimentales o por celos literarios. Fue, como puede imaginarse, sensacional el proceso judicial y tuvo gran resonancia en la prensa del día ${ }^{47}$. Cumplida la condena y puesto en libertad, Vidal y Planas, acompañado de su mujer, emigró a los Estados Unidos doctorándose en filosofía ${ }^{48}$. Termi-

$46^{\circ}$ J. López Pinillos («Pármeno»), «Tropiezos de Vidal y Planas», Vidas pintorescas. Gente graciosa y gente rara, 261-270.

47 José Fernando Dicenta reconstruye de El Sol los detalles del proceso, La santa bohemia, 190-207.

48 En su libro Raros y olvidados, Madrid, Editorial Prensa Española, 1971, 167, Federico Carlos Sainz de Robles recoge este dato, y afirma que también enseñó por algún tiempo en la Universidad de Fordham en Nueva York, hecho que no he podido comprobar. 
na su larga vida en Tijuana (México), hacia 1952, impartiendo clases en un Instituto. Publica un último libro con título de Cirios en los rascacielos y otros poemas (Poemas del destierro, de Yanquilandia y de la muerte), Ediciones Grillo, Tijuana, 1963. También el modesto libro lleva un afectuoso prólogo de Cansinos-Assens (13-16), fiel a la vieja amistad que le unía con el desventurado autor del libro. Reconoce en Vidal y Planas su idealismo espiritual, que le obliga a poner su pluma al servicio de los desvalidos, y escribe: «Tus exaltaciones de antaño han cuajado en máximas de vida, en instituciones luminosas, y tu lectura, que antes llamaba a guerra, invita ahora a la paz, a la serenidad de espíritu que confiere una fe...» (15).

Basta una rápida descripción del libro, poco conocido, que comprende con ciertas excepciones poesías fechadas desde 1937, principalmente en Nueva York. También la quinta parte incluye cinco textos en verso de 1912 tomados de libros anteriores escritos en prosa. Ciertas constantes se repiten en la poesía de Vidal y Planas. Antes que nada el libro se llena de presagios y anticipos de la muerte, una presencia tenaz y concreta. Por momentos, parece resucitarse la fe perdida del exseminarista; se da cuenta de que llega al término del camino, y, preocupado por el reposo de sus huesos, está preparándose para la partida definitiva. La muerte, pues, es la última verdad que le queda y no la teme, sino que la acoge con evidente resignación ( El cepo de la Verdad. Breve espístola a los sabios»). A menudo una sincera y conmovedora nostalgia por la patria se revela como sentimiento dominante en varios poemas y pide que lo entierren en España. La visión de Nueva York es en más de un sentido parecida a la de los grandes poemas de García Lorca inspirados en la misma realidad de cemento y metal, rascacielos y cementerios. A pesar de la deshumanización que halla a su alrededor Vidal y Planas, como Lorca se siente solidario con sus entrañables hermanos de Harlem («El tatuaje de Harlem»). Leamos la siguiente estampa de la ciudad, exacta en sus detalles: «Grandes puentes de acero / sobre ríos enormes, / negros, quietos, medrosos, / con peces de metal / y barcas de Caronte: / iríos que pescan truchas de suicidas / saltando de los puentes... / Túneles bajo el mar; / carreteras colgantes; / áereos trenes rápidos, / que vuelan con estruendo / sobre las chimeneas, / espantando a los gatos... / Audaz ingeniería / humana, sólo humana!» De los seis poemas agrupados en «Cancionero franciscano» es especialmente conmovedora la composición en que la cama de la prostituta se purifica por la presencia de un perro ciego, que algo divino tiene, y que ha sido 
recogido por ella de la calle ( $(\mathrm{El}$ perro ciego de La Perdida»). El libro termina con un texto delirante, de locura e incoherencia, titulado «Última pintura de Abel Cruz», alter ego de Vidal y Planas, como se recordará. Desde las alturas de su peregrinación, lejos de la añorada patria, siente viceralmente la presencia de la muerte, no como motivo de miedo sino de descanso. Por último, vuelven a surgir imágenes de antaño en estos versos de «Copla»:

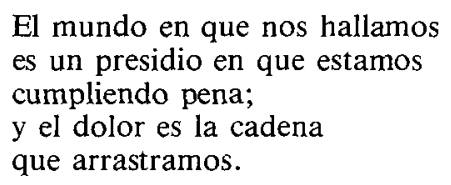

\section{Un último poeta: Xavier Bóveda}

Sin exceder los límites cronológicos del presente trabajo, aún hay tiempo para referirme a otro escritor que hizo por algún tiempo vida de bohemia en Madrid y que militó, como Puche, en las filas del Ultraísmo: el poeta gallego Xavier Bóveda (1898-1963). Lo llama CansinosAssens: «Hijo de la naturaleza pervertido por la literatura bohemia de Carrère $>{ }^{49} \mathrm{y}$, llegado a la ciudad, pronto se hizo amigo de los hampones literarios, especialmente de Gálvez, llevando por un breve período una misera vida de bohemio. De aquellos tiempos juveniles datan estos versos, cuando era, según confesión propia, hampón y anarquista:

\footnotetext{
Eran los cafetines mis ocultos cenáculos; a rameras y hampones les dije los oráculos de un religioso libro de humana devoción.

Parti con los bohemios mi pan empobrecido, $\mathrm{y}$, al pensar en mi vida, el dolor he sentido de tener corazón.
}

(«Del vivir doliente, II»)

Terminada la Primera Guerra Mundial, Bóveda emigró a Buenos Aires hacia 1923, y su trayectoria lírica se prolongó con la publicación de varios títulos en la ciudad porteña, donde fundó además la revista Síntesis, de larga vida ${ }^{50}$.

50) Hay más datos sobre Bóveda en el retrato que hace Gómez de la Serna de Pedro Luis Gálvez, amigo del poeta gallego en sus primeros años madrileños. Nuevos retratos contemporáneos, 159-189. 
Bóveda no sólo colaboró de modo asiduo en las revistas de Ultraísmo, sino que también celebró con Cansinos-Assens una importante entrevista publicada en El Parlamentario, que se considera el nacimiento oficial del nuevo movimiento artístico ${ }^{51}$. No tarda mucho en salir el primer manifiesto del Ultraísmo (otoño de 1918), en el cual se aprueba la orientación renovadora señalada por Cansinos, y su lema será desde luego ultra. La historia de esa entrevista continúa en el comentario que el crítico hace de otro libro de Bóveda, el titulado Poemas de los pinos $^{52}$.

Aquí me concierne un solo libro de Bóveda titulado Epistolario romántico y espiritual. Rosario lírico y otros poemas (Orense, Imp. de la Región, 1917), de contenido misceláneo, que es una hermosa colección de los tempranos versos de un joven poeta en busca de su personalidad a pesar de la profunda herencia de la maestría de Darío, a quien se dedica un largo poema «Homenaje a Rubén Darío». Hay en el libro también una seria e impecable adaptación de «Era un aire suave», poema en el cual se cuenta la historia de la divina Eulalia envejecida en la larga espera al amante ideal («La vejez de Eulalia»). Tras un «anteprólogo» (9-15) y un prólogo crítico (19-29) de Couceiro Freijomil, el autor confiesa que el libro es la historia doliente de su vida de aventurero y poeta: «Mi destino es soñar, y pensar y vivir / la Vida en un Momento donde se funda el Todo; / mis labios solo saben besar y sonrreir / mientras dispongo mi alma para el eterno exodo («Autorretrato, III»).

Por su contenido tan variado es difícil reducir a síntesis el alcance del poemario de Bóveda, rico en temas y tonos diferentes. Se trata de una poesía esencialmente modernista que elimina casi por completo las notas feas de una realidad embellecida. Formalmente prefiere el soneto, tanto el endecasílabo como el alejandrino, y hasta uno de tema amoroso se titula «En un soneto clásico y a un tiempo modernista». Su Modernismo, a veces versallesco y primaveral, de música cadenciosa y sensualista, casi siempre regala al lector versos de refinada belleza:

En el ánfora roja de tus labios divinos libé la miel panida de todos mis ensueños,

s Gloria Videla publica íntegro el texto, sin poder precisar con exactitud la fecha, en su informativo libro El ultraísmo, Madrid, Editorial Gredos, 1971, $31-94$.

52 Ibidem, p. 37, n. 19. 
Canta también los temas de la decadencia como atestiguan los siguientes versos: «Mientras hilan las Parcas el lino de mi Vida, $\$$ y en tanto que Caronte se aduerme en la ribera, / quiero buscar la senda, ensoñada y florida, / donde las rosas viven eterna Primavera: / En el tiempo se ha hundido ya la etapa primera / de las seis de mi Vida... Yo hoy busco la fragancia / del vino que, en la copa del Placer, siempre escancia / la mano luminosa de una Santa Quimera» («Las flores del bien y del mal, I»). En su jardín de amor parece que se rechaza a las mujeres sensuales, porque les falta un genuino sentimiento amoroso, y se abre camino a una mujer ideal, de alma blanca, que «en mis horas de angustia ilumine mi vida / con la luz de los besos de su boca galana» (Ibidem, III). Junto con el ambiente galante de sus exaltados madrigales, hay de cuando en cuando otros momentos de recogimiento, y se impone una nota bucólica de paz y silencio ( «Mañana primaveral»). En otra ocasión reconoce su deuda con Manuel Machado («Hermano poeta»), y confiesa que también su voluntad ha muerto entre las sombras y se refugia en la calma de la noche. Sin embargo, Bóveda quiere unir su vida de soñador con la de la realidad vivida, pero se siente perseguido por la fatalidad de la luna al intentar realizar su empeño de ser sueño y realidad al mismo tiempo («De mi yo interior», I, II). Entre los poemas finales, en su mayoría medallones y semblanzas (Rosalía Castro, Curros Enríquez), hay una larga composición titulada sencillamente «Ramón María del Valle-Inclán», sentido homenaje al admirado escritor, que revela una íntima compenetración con las notas más esenciales de la obra de su paisano. De nuevo suena la voz milenaria y céltica de Galicia, mística y pagana a la vez. Y ésa es la atmósfera con que anhela identificarse Bóveda, un artístico regionalismo auténtico. 